\title{
How a stationary knickpoint is sustained: New insights into the formation of the deep Yarlung Tsangpo Gorge
}

Yizhou Wang ${ }^{1 *}$, Huiping Zhang ${ }^{1}$, Dewen Zheng ${ }^{1}$, Wesley von Dassow ${ }^{2}$, Zhuqi Zhang ${ }^{1}$, Jingxing $\mathrm{Yu}^{1}$, and Jianzhang Pang ${ }^{1}$

\begin{abstract}
In order to test the hypothesis that the stationary nature of the Yarlung Tsangpo Gorge is tectonically controlled, the rock uplift pattern in the southeast Tibetan Plateau and the critical condition to sustain a stable knickpoint must be derived. Via slope-area analysis and the integral approach, we first quantify the pattern of channel steepness in southeast Tibet and find that the steepness index shows higher values around the gorge but lower values toward the inner land and the mountain front. Such a pattern of channel steepness indicates that the active rock uplift is restricted in the zone just around the Yarlung Tsangpo Gorge. Then, we derive a general knickpoint migration model that accounts for spatially variant rock uplift rates. From the model, a critical condition for maintaining a stable knickpoint is concluded that the difference of incision rates in the downstream and upstream reaches of the knickpoint should match that of rock uplift. Employing a streampower river incision model, we calculate the incision rate in the gorge and find a higher correspondence with differential rock uplift rates in the downstream and upstream reaches of the knickpoint. Therefore, we favor tectonic control as the primary mechanism to explain the stability of the knickpoint within the Yarlung Tsangpo Gorge.
\end{abstract}

Keywords: the stationary Yarlung Tsangpo Gorge; tectonic control; stream profile analysis; channel steepness 


\section{Introduction}

The Tibetan Plateau, resulting from the continuous convergence of the Indian and Eurasian plates, is the highest plateau on Earth. With a mean elevation exceeding $4000 \mathrm{~m}$, enormous relief exists between the plateau and the surrounding basins, such as the Sichuan Basin and Tarim Basin (Kang, 2014). Of the plateau as a whole, southeast Tibet exhibits the greatest relief of more than $6000 \mathrm{~m}$ (Sun, 2014). Furthermore, rock uplift and precipitation gradient (from $>4000 \mathrm{~mm}$ near the mountain front to $<1000 \mathrm{~mm}$ on the plateau) are higher in the SE Tibetan Plateau than in any other region of the plateau (Zhong and Ding, 1996; Zhang et al., 2004; Anders et al., 2006; Enkelmann et al., 2009, 2011; Bookhagen and Burbank, 2010). Tectonics and climate have played important roles in the formation of the Tibetan Plateau and the sustainment of the high topography. A common viewpoint is that tectonic and erosion (may be caused by precipitation, surface runoff, and glaciers) processes create, amplify, and reduce topography (Willett, 1999; Burbank et al., 2003; Molnar et al., 2007; Zeitler et al., 2009; Champagnac et al., 2012; Zhu et al., 2012; Zhang et al., 2014). However, whether tectonics or climate contributes more to forming or sustaining inland high topography is still under debate (Molnar and England, 1990; Beaumont et al., 2001; Zeitler et al., 2001; Zhang et al., 2001; Wang et al., 2014).

A large number of rivers, for example, the Yarlung Tsangpo, Nujiang, Lantsang, and Jingsha rivers, flow through the SE Tibetan Plateau. These rivers exhibit flat stream profiles and broad U-shaped valleys (Wang et al., 2002; Yu et al., 2011) within the plateau. At the plateau margin, elevation decreases sharply from more than $4000 \mathrm{~m}$ to less than $2000 \mathrm{~m}$, generating steep river profiles and deep V-shaped valleys (Zeitler et al., 2001;

Clark et al., 2006; Sun, 2014; Wang et al., 2014). The channel incision rates downstream of large knickpoints are usually high, leading to the formation of deep gorges. Questions remain, such as whether rapid erosion controlled by knickpoint migration at the plateau margin will affect the inner topography. Therefore, studying the formation of gorges and knickpoint stability on large rivers will help to reveal the factors that contribute to the formation of and to the sustaining topography of the Tibetan Plateau.

The Yarlung Tsangpo Gorge is the result of rapid incision localized downstream of the stationary Yarlung Tsangpo knickpoint (Figs. 1A and B; Finnegan et al., 2008). Dropping by $2 \mathrm{~km}$ in elevation as it cuts through the $\sim 50$ - $\mathrm{km}$-wide eastern Himalayan syntaxis, the gorge is the steepest (mean slope $\sim 2 \%$ ) in the Himalaya, and probably on Earth (Wang et al., 2014). The high river incision rates (1-10 mm/a; Finnegan et al., 2008) 
contribute $\sim 50 \%$ of total detritus to the sediment load of the Brahmaputra (Bracciali et al., 2016). Young zircon $(\mathrm{U}-\mathrm{Th}) / \mathrm{He}(<3 \mathrm{Ma})$ and biotite ${ }^{40} \mathrm{Ar} /{ }^{39} \mathrm{Ar}(<6 \mathrm{Ma})$ cooling ages are all spatially colocated along the Yarlung Tsangpo Gorge (Zeitler et al., 2014), indicating that the location of rapid incision has not propagated upstream and that the Yarlung Tsangpo knickpoint has been stationary (at least for $6 \mathrm{Ma}$ ). Knowledge about what constrains the formation of the gorges is critical to understand how climate and tectonics have played roles in the formation and sustainment of the high topography of the inner SE Tibetan Plateau. Korup and Montgomery (2008) proposed a glacial dam hypothesis to explain the formation of the Yarlung Tsangpo Gorge. According

to their hypothesis, moraine dams on major rivers impede incision into the southeastern edge of the Tibetan Plateau. Through upstream impoundment and interglacial aggradation, the knickpoint is sustained and river incision was focused within the gorge, further contributing to a locus of rapid exhumation, known as tectonic aneurysm (Zeitler et al., 2001). On the other hand, Wang et al. (2014) proposed a tectonic control mechanism for the formation of the gorge. They showed that steepening of the Yarlung Tsangpo Gorge could have been caused by an increase in rock uplift rates that initiated in the early Pleistocene, suggesting that the rapid erosion was a consequence, not a cause, of rock uplift. However, which one would be reasonable or whether both hypotheses can be relevant is still confusing.

In this paper, we first quantify the pattern of channel steepness in the SE Tibetan Plateau to illustrate whether active rock uplift is restricted in the zone around the gorge. Then, we derive a critical condition for maintaining a stable knickpoint from a general knickpoint migration velocity formula. We calculate the rock exhumation rates, channel steepness, and erodibility of the Yarlung Tsangpo Gorge. Combining these parameters, we obtain the river incision rate at the gorge. Finally, we compare the incision rate and the rock uplift rate along the gorge and the upstream reach of the river to test whether localized rock uplift (tectonic control) can be the primary mechanism for knickpoint stability of the Yarlung Tsangpo Gorge.

\section{Regional setting}

The eastern syntaxis of the Himalaya, located $94^{\circ} 20^{\prime}-95^{\circ} 40^{\prime} \mathrm{E}$ and $29^{\circ} 20^{\prime}-30^{\circ} 20^{\prime} \mathrm{N}$ (Fig. 1B), is the eastern termination of the dominantly E-W-trending Himalayan orogenic belt. The syntaxis is expressed as a northeast plunging antiform and a southward bend in the crest line (Zeitler et al., 2014). As a transition between thrust-fault-dominated tectonics in the Himalayas and the strike slip tectonic regime of Southeast Asia, the region is constrained by the Jiali Fault (NWW trending, right-lateral) in the north, Dongjiu-Milin 
Fault (NE trending, left-lateral) in the west, and A'niqiao Fault (NE trending, left-lateral) in the east (Fig. 1A; Booth et al., 2009). Around the eastern syntaxis is Lhasa block, which consists of low to medium metamorphic grade sedimentary rocks, granite, layered gneiss, and Gangdese plutons (Fig. 1C; Zeitler et al., 2014). The interior of the eastern syntaxis is Himalaya Block, which is differentiated between the Namche Barwa antiform to the southwest of the Nam-la thrust fault and the Namche Barwa massif to the northeast (Zeitler et al., 2014). The former one is composited of Namche Barwa gneisses and the latter is occupied by low- to mediumpressure granulite-grade rocks (Booth et al., 2009). Rocks here have experienced at least two metamorphic episodes, the first at high pressures and temperatures $\left(14-15 \mathrm{kbar}\right.$ and $\left.\sim 800^{\circ} \mathrm{C}\right)$ and the second by nearisothermal decompression to 8-10 kbar (Zhong and Ding, 1996; Liu and Zhong, 1997).

Owing to the intense tectonics, pronounced precipitation gradient (from $>4000 \mathrm{~mm}$ in the Himalaya front to $\sim 200 \mathrm{~mm}$ beyond the Tsangpo Gorge, within a short horizontal distance of about $150 \mathrm{~km}$ ), and glacier activity in the high elevation, the erosion rate here can be as high as up to $6 \mathrm{~mm} / \mathrm{a}$ (Finnegan et al., 2008). Together with prominent high peaks (e.g., Gyala Peri and Namche Barwa, both higher than $7000 \mathrm{~m}$ ) and through cutting river gorges (e.g., the Yarlung Tsangpo Gorge, dropping from about 2950 to $1000 \mathrm{~m}$ ), the relief of the steep glacially and fluvially dissected terrain is defined to be $>6 \mathrm{~km}$ (Fig. 1B). Thermochronologic studies, for example, zircon U-Th/He, show a pattern of youngest ages $(<2 \mathrm{Ma})$ located just around the Yarlung Tsangpo Gorge, while older ages ( $\sim 10$ to $>50 \mathrm{Ma})$ are outside the gorge (Fig. 1B; Zeitler et al., 2014). Based on the analysis of detrital minerals in Himalayan foreland basin deposits, Lang et al. (2016) concluded that rock exhumation in the core of the syntaxis accelerated in the late Miocene and have sustained extremely rapid rates $(>5 \mathrm{~mm} / \mathrm{a})$ since $5 \mathrm{Ma}$. Via analyzing previous work that focused on the eastern syntaxis and new chronological data (zircon and rutile $\mathrm{U}-\mathrm{Pb}$, white mica $40 \mathrm{Ar} / 39 \mathrm{Ar}$, and zircon fission track) on its bedrock and erosion products, Bracciali et al. (2016) showed that the inception of rapid syntaxial exhumation might have started as early as $7 \mathrm{Ma}$ or as late as $3 \mathrm{Ma}$.

Provenance studies from the Himalayan foreland indicate that a connection between the Yarlung Tsangpo and Brahmaputra River was already established before the middle Miocene (Cina et al., 2009; Chirouze et al., 2013; Lang and Huntington, 2014), emphasizing the stability of the gorge. The young zircon (U-Th)/He cooling ages $(<3 \mathrm{Ma})$ and high river incision rates $(1-10 \mathrm{~mm} / \mathrm{a})$ are all spatially colocated along the Yarlung Tsangpo Gorge, which demonstrates that the Yarlung Tsangpo knickpoint has long been stationary since the late Pliocene or early Pleistocene (Finnegan et al., 2008). 


\section{Stream profile analysis}

To test the hypothesis of 'localized rock uplift contributes to the stationary of the gorge', the most important is to make sure whether active rock uplift is restricted in the zone localised around the Yarlung Tsangpo Gorge. Although thermochronologic studies show the most rapid exhumation along the gorge, interpreting it to be rock uplift is difficult owing to the complex climatic and lithologic conditions.

Channel steepness has been demonstrated to be a good indicator of rock uplift in a lot of areas (Snyder et al., 2000; Kirby and Whipple, 2001; Kirby et al., 2003, 2007; Wobus et al., 2006; Hu et al., 2010). In this contribution, we derive the channel steepness of the streams based on a power-law scaling between drainage area $(A)$ and channel gradient $(d z / d x)$ (Flint, 1974; Howard and Kerby, 1983; Snyder et al., 2000; Wobus et al., 2006; Goren et al., 2014a, b):

where $z$ is channel elevation, $x$ is upstream distance, $E$ is river incision rate, $K$ is channel erodibility (related to many factors, e.g., precipitation, lithology, and sediment flux), $m$ and $n$ are constant exponents, and are channel steepness and concavity, respectively. For steady state, river incision rate $E$ is equal to rock uplift rate $U$; steepness can be related to rock uplift.

Two methods have been widely used to derive stream power parameters, channel concavity $\theta$ and steepness $k_{s}$ in many studies (Kirby et al., 2003, 2007; Wobus et al., 2006; Perron and Royden, 2013). With a linear regression of the log-transformed slope-area data, the slope and intercept are channel concavity and logarithm of steepness, respectively, which is the so-called slope-area analysis method (Wobus et al., 2006). For the integral approach (Perron and Royden, 2013), $\chi-z$ plots are generated by integrating Eq. (1), as shown into Eq. (2):

Throughout the paper, we set the area-scaling factor $A_{0}=1 \mathrm{~m}^{2}$. Then, the slope of the $\chi-z$ plot is channel steepness. Owing to the heavy dependence of on $\theta$, a reference concavity index is needed to derive the pattern of channel steepness.

\subsection{Reference concavity index}

To determine the reference concavity index $\theta$, we extract the trunk river and more than 200 tributaries of the whole Yarlung Tsangpo drainage basin (inset map of Fig. 1A) and calculate the related $\chi-z$ plots based on a 
range of $\theta$ values (Figs. 2A-C). The elevation data of SE Tibet (Fig. 1A) are from SRTM digital elevation model (DEM) with a solution of $90 \mathrm{~m}$ (http://srtm.csi.cgiar.org/SELECTION/inputCoord.asp). The topographic data localized in the gorge (Fig. 1B) are rectified by Aster Global DEM (http:// earthexplorer.usgs.gov/) for the poor data quality of the SRTM DEM. We chose a $\theta$ value that minimizes the elevation scatter in the $\chi-z$ curves. We subdivided the $\chi$-space into 100 bins. The scatter is defined by the mean of the distribution over the standard deviation of elevation in each of the bins (Goren et al., 2014a). Minimum scatter occurs when $\theta=0.5$ (Fig. 2D).

\subsection{The pattern of channel steepness, $k_{s}$}

We calculated the channel steepness $k_{s}$ via the integral approach. The steepness indices for the trunk stream and $\sim 140$ tributaries of the Yarlung Tsangpo Gorge are shown in Fig. 3. The steepness indices of the trunk river segments are much larger than that of the tributaries. Channel steepness shows the maximum value $(8838.03 \mathrm{~m})$ at the gorge and decreases toward the downstream and upstream reaches. The minimum value $(487.93 \mathrm{~m})$ is located upstream of the gorge. For the tributaries, the high steepness values (1000-2000 m) are all restricted in the zone adjacent to the gorge. Away from the gorge, the trunk channel and its tributaries exhibit lower steepness. Obviously, the areas with higher steepness values are also characterized by younger annealing ages (Fig. 3). To interpret the relationship between channel steepness and local rate of differential rock uplift, some other factors (e.g., climate, lithology, and sediment flux) must be discriminated, which will be discussed in section 5.1.

\section{A critical condition to sustain a stable knickpoint}

\subsection{Upstream migration of a knickpoint}

Despite various potential controls on knickpoint formation, for example, variant rock uplift rates (Goren et al., 2014a), earthquakes (Cook et al., 2013), extreme flood events (Lamb et al., 2014; Baynes et al., 2015), sea level fall (Mackey et al., 2014), and lithological boundaries (Haviv et al., 2010), we focused on tectonically controlled knickpoints along bedrock river profiles. Their locations and migration velocity may present an opportunity to extract rock uplift/incision history (Kirby and Whipple, 2012). Assumptions, such as spatially invariant rock uplift rates and a linear relationship between incision and local channel gradient, are applied in 
many previous models for the evolution of the knickpoint (Rosenbloom and Anderson, 1994; Berlin and Anderson, 2007; Goren et al., 2014a; Fox et al., 2015). However, the Yarlung Tsangpo River has experienced spatial and temporal variation in rock uplift rates (Sun, 2014; Wang et al., 2014), thus the suitability of the assumptions made in those models needs to be reevaluated. Here we derive a general knickpoint migration velocity (horizontal velocity $v$ ), which accounts for spatial variation in rock uplift and for a nonlinear relationship between erosion and channel gradient.

Figure 4 shows a knickpoint migrating from point A to $\mathrm{D}$ in a time step $d t$ (from time $t$ to $t+d t$ ). The river profile varies from $z_{t}$ to $z_{t^{+} d t}$, simultaneously. The elevation change of the knickpoint is described by Eq. (3):

Segments AC and BD represent the difference of rock uplift rate and stream incision rate at points A and B, respectively. The segment BG is the elevation difference of the original profile. These can be expressed as Eqs. (4)-(6):

where $U$ is rock uplift rate $\left(U_{A}\right.$ and $U_{B}$ are rock uplift rates in the reaches downstream and upstream of the knickpoint, respectively); $E$ is river incision rate ( $E_{A}$ and $E_{B}$ are river incision rates in the reaches downstream and upstream of the knickpoint, respectively); the subscript $D n$ means a reach downstream of the knickpoint; $U p$ means a reach upstream of the knickpoint; and $v$ is the horizontal velocity of a knickpoint migration upstream.

By plugging Eqs. (4)-(6) back into Eq. (3) and arranging it, we get a velocity formula:

Using a stream-power based channel incision model, incision rate can be viewed as the product of erodibility $K$, drainage area $A$, and channel gradient:

Thus, the horizontal velocity of a knickpoint migration upstream may be derived as Eq. (9). Parameters in these formulas are shown in Table 1. 


\subsection{A simple schematic figure to the model}

In order to demonstrate Eq. (9), we simulated knickpoint evolution in cases of rock uplift at uniform (Figs. 5A and B) and nonuniform (Figs. 5C-H) rates. A knickpoint separates the river profile into two different segments: a gentle upstream reach and a steep downstream reach. In the case of a spatially uniform rock uplift rate, steep downstream channels are eroded faster than upstream channels, resulting in a relief between the two sides of the knickpoint (Fig. 5A). This causes rapid incision and subsequent upstream migration of the knickpoint (Fig. 5B). While the channel is subject to a steady state downstream of the knickpoint, elevation of reaches downstream of the knickpoint may no longer change, i.e., points A and C (Fig. 4) may overlap. In this case, the migration velocity of the knickpoint can be simplified to Eq. (10):

If the river experiences variations in uplift rate through time, knickpoints generated at different times (subject to different uplift rates) may result in channels with different channel steepness indices. For the nonlinear condition $(n \neq 1)$, those knickpoints migrate at different rates, which may cause stretch zones or consumption of knickpoints (Royden and Perron, 2013). Assuming a linear relationship between stream incision rate and local channel gradient $(n=1)$, Eq. (10) can be simplified to $v=K A^{m}$. Despite the control of river sediment flux and tectonic uplift on a fluvial system (Humphrey and Konrad, 2000), the influence of waterfalls and knickzones on landscape adjustment (DiBiase et al., 2015), and the lack of absolute one-to-one correlation between knickpoints along river profiles and base-level events (Grimaud et al., 2016), this simplified formula for knickpoint migration can also be used to extract rock uplift/incision history (Rosenbloom and Anderson, 1994; Zhang et al., 2011; Fox et al., 2014; Rudge et al., 2015).

When rock uplift rate is faster downstream, elevation difference around a knickpoint may decrease (Figs. 5C and D), and upstream migration of the knickpoint tends to slow down as a result. When incision downstream of the knickpoint is compensated by uplift, the knickpoint may become stationary (Figs. 5E and F). Subsequently, deposition may occur upstream of the knickpoint if rock uplift outpaces erosion (Figs. 5G and $\mathrm{H}$ ). Hence, we may derive the critical condition necessary for sustaining a knickpoint using Eq. (11):

In addition, clusters of moraine dams can trap sediment and impede trunk-river incision into bedrock (Korup and Montgomery, 2008). In this case, continuous deposition upstream of the knickpoint should match downstream incision to protect the bedrock from further erosion and to keep the knickpoint stationary. 


\subsection{Parameters related to critical condition}

To determine whether a knickpoint is stable, we need to solve for all parameters in Eq. (11). We utilized the method of Goren et al. (2014a). To simplify the problem, we assumed $n=1$ (Whittaker et al., 2007; Pritchard et al., 2009; Whittaker and Boulton, 2012). We will give a simple explanation to the reasonability of the linear assumption in section 4.3.2.

\subsubsection{Channel gradient and steepness index}

To calculate the channel gradient, we extract the trunk river profile from drilling no.1 (the green star labeled '1' in Fig. 1A; Wang et al., 2014) to a point (named 'origin') in the downstream reach (Fig. 1A). This profile, shown in Fig. 6A, is divided into four segments for distinct river slope. Applying a bivariate linear regression of elevation and distance, the average channel gradient is $2 \%$ and $0.1 \%$ for the gorge and its upstream reach, respectively. The steepness index of the Yarlung Tsangpo Gorge is $8838.03 \mathrm{~m}$ from the bivariate regression of elevation and $\chi$ (Fig. 6B). This value is much larger than that of other areas (Snyder et al., 2000; Kirby and Whipple, 2001; Kirby et al., 2003; Wobus et al., 2006; Goren et al., 2014a), which owes to the higher river drop, drainage area, and reference concavity index for the Yarlung Tsangpo Gorge.

Although a stream profile usually shows different forms in plots of distance-elevation and $\chi-z$, knickpoints can be recorded in both. The concavity of the gorge is more than 400 (Fig. 6C). Thus, in spite of a mean steepness value derived from the $\chi-z$ plot, the local channel steepness indices (calculated with a length step of 5 km; Fig. 5D) vary significantly along the gorge when a low reference concavity $m=0.5$ is used (when applying linear assumption $n=1, \theta$ is equal to $m$ ). The varied steepness indices indicate many secondary knickpoints along the gorge in addition to the huge knickpoint separating the gorge and its upstream reaches. These knickpoints and river segments with variable steepness and gradient can be recorded in $\chi-z$ and in distance-elevation plots, which may result in a similar shape of the two plots (Figs. 6A and B).

\subsubsection{Erodibility, $K$}

From Eqs. (1) and (2), we present a relationship between channel steepness index $k_{s}$, erodibility $K$, and river incision rate $E$ : 
From Eq. (12), whether a linear relationship exists between channel steepness and erosion rate depends on the slope exponent $n$. The linearity assumption $(n \sim 1)$ can also be determined via regressing $k_{s}$ and $E$ (Safran et al., 2005; Cyr et al., 2010; DiBiase et al., 2010). Employing a bivariate linear regression to incision rate and steepness can illustrate whether the linearity assumption $(n \sim 1)$ is reasonable in calculating the erodibility.

We take the rock exhumation rate in the gorge as a proxy of the river incision rate $E$ (Goren et al., 2014a). A great body of work has been done to report the thermal annealing age here. For a portion of the gorge, the biotite ${ }^{40} \mathrm{Ar} /{ }^{39} \mathrm{Ar}$ annealing age is much greater than $2 \mathrm{Ma}$ (Fig. 1B) (Gong et al., 2008, 2015; Seward and Burg, 2008). This is outside of the time scale of our discussion. Furthermore, the local geothermal gradient is higher than $65^{\circ} \mathrm{C} / \mathrm{km}$ (Nie, 2015), meaning that those mineral chronometers with low closure temperatures, e.g., Apatite (U-Th) $/ \mathrm{He}\left(40-70^{\circ} \mathrm{C}\right.$; from Wolf et al., 1996) and Apatite Fission Track $\left(60-120^{\circ} \mathrm{C}\right.$; from Naeser, 1979; Wagner, 1979; and Braun et al., 2006), will begin annealing at a depth of $<1 \mathrm{~km}$. In this case, small changes in surface erosion and horizontal advection may cause significant variation in mineral age.

The Zircon (U-Th)/He annealing age of the gorge is $0.2-1.2 \mathrm{Ma}$ (Fig. 6A), which is suitable for the time scale of gorge incision. Most samples along the trunk river upstream and downstream of the gorge indicate young annealing ages $(<10 \mathrm{Ma}$; Fig. 6A), which may indicate rapid exhumation since the late Miocene. Those samples with higher elevation $(>3600 \mathrm{~m}$ ) are excluded owing to old age (older than $30 \mathrm{Ma})$. Zircon (U-Th)/He also has a relatively high closure temperature of $\sim 200$ to $>280^{\circ} \mathrm{C}$ (Zaun and Wagner, 1985; Tagami et al., 1995; Tagami and Shimada, 1996), which may be insensitive to the difference of surface erosion or horizontal advection. Given this, we may derive a comparatively stable average for exhumation rate.

We apply a one-dimensional, steady-state thermal diffusion model to calculate exhumation rates. This method works well for the He and FT thermochronometers (Reiners and Brandon, 2006) even when horizontal velocities within the orogen are significant (Batt and Brandon, 2002). Modeling and calculations were completed using the AGE2EDOT software (http://campuspress.yale.edu/markbrandon/software/386-2/). We selected parameters after Nie (2015), including basement temperature $\left(1150^{\circ} \mathrm{C}\right)$, ground temperature $\left(0^{\circ} \mathrm{C}\right)$, rock heat production rate $\left(6.5^{\circ} \mathrm{C} / \mathrm{Ma}\right)$, thermal diffusion coefficient $\left(25 \mathrm{~km}^{2} / \mathrm{Ma}\right)$, and geothermal gradient (discounting erosion) $20^{\circ} \mathrm{C} / \mathrm{km}$. This results in the rock exhumation rates demonstrated by Fig. 7 .

Comparing rock exhumation rates to previously calculated channel steepness indices along the trunk river and its tributaries (Figs. 3 and 6D), we observe a good linear relationship $\left(\mathrm{R}^{2}=0.79\right)$ (Fig. 8), showing that our linearity assumption $(n=1)$ is reasonable. Thus, according to Eq. (12), the slope of the regression line, $(6.23 \pm 0.06) \times 10^{-7} / \mathrm{a}$, is equal to erodibility, $K$. 


\subsection{Comparison of the two hypotheses}

\subsubsection{Glacial dam}

Korup and Montgomery (2008) considered that 'clusters of moraine dams trap sediment and impede trunk-river incision into bedrock'. Knickpoint migration results from the differential erosion between its downstream and upstream reaches. Thus, deposition in the upstream should match incision in the gorge to protect the upstream channel bedrock from further erosion. Based on the gorge drainage area (2.08-2.38) $\times$ $10^{11} \mathrm{~m}^{2}$, erodibility $K(6.23 \pm 0.06) \times 10^{-7} / \mathrm{a}$, and mean slope $(0.02)$, the mean stream incision rate is $(5.83 \pm 0.35)$ $\times 10^{-3} \mathrm{~m} / \mathrm{a}$ by the model of this study, corresponding to the mean value $\left(\sim 5.5 \times 10^{-3} \mathrm{~m} / \mathrm{a}\right)$ of Finnegan et al. (2008).

Although the incision rate estimated in this study is just a mean value, the minimum incision rate in the Yarlung Tsangpo Gorge should be larger than $1 \times 10^{-3} \mathrm{~m} / \mathrm{a}$ (Finnegan et al., 2008). Wang et al. (2014) showed that upstream deposition initiated at $\sim 2.5 \mathrm{Ma}$, resulting in an overall mean thickness of $500 \mathrm{~m}$ and an average deposition rate of $\sim 0.20 \times 10^{-3} \mathrm{~m} / \mathrm{a}$. This is considerably lower than the gorge incision rate, which means that glacial damming alone could not result in a stable Yarlung Tsangpo Gorge.

\subsubsection{Tectonic control}

According to the tectonic control hypothesis, the difference of incision rates upstream and downstream of the knickpoint must match that of bedrock uplift rates (Fig. 5). As shown by Fig. 9, the black dashed line indicates the valley bottom before the uplift of the Yarlung Tsangpo Gorge, which is a graded profile resulting from the upstream erosion of the Yarlung Tsangpo $2.5 \mathrm{Ma}$ (Wang et al., 2014). Comparing the previously graded river profile and the present gorge, the gorge surface has been uplifted by $0-1 \mathrm{~km}$ over the past 2.5-3 $\mathrm{Ma}$, which results in an average surface uplift rate of $\sim 0.2 \times 10^{-3} \mathrm{~m} / \mathrm{a}$. From the mean gorge incision rate $(5.83 \pm 0.35) \times 10^{-3} \mathrm{~m} / \mathrm{a}$, the rock uplift rate of the gorge is $\sim(6.03 \pm 0.35) \times 10^{-3} \mathrm{~m} / \mathrm{a}$, which is similar to the uplift rate $\left(\sim 6 \times 10^{-3} \mathrm{~m} / \mathrm{a}\right.$, derived from GPS data) of the Himalaya range with respect to its south foot (Liang et al., 2013).

In Fig. 9, the thick gray curve upstream of the gorge is the bedrock valley bottom reconstructed by an artificial neural network (Wang et al., 2014). The upstream reach, between points H and L (Fig. 9), has experienced relatively lower rock uplift for its correspondence with the graded profile. However, the reach 
between points $\mathrm{J}$ and $\mathrm{H}$ has been uplifted by about $0-1 \mathrm{~km}$. This results in a mean rock uplift rate $\sim 0.2 \times 10^{-3}$ $\mathrm{m} / \mathrm{a}$ for the upstream. Then, the difference of rock uplift rates between the gorge $\left(\sim 6.03 \times 10^{-3} \mathrm{~m} / \mathrm{a}\right)$ and its upstream reach $\left(\sim 0.2 \times 10^{-3} \mathrm{~m} / \mathrm{a}\right)$ is $5.83 \times 10^{-3} \mathrm{~m} / \mathrm{a}$. As a deposition zone, the incision of the upstream reach can be neglected. Then, the difference of incision rates between the gorge and its upstream reach is $6.03 \times 10^{-3}$ $\mathrm{m} / \mathrm{a}$. Thus, the difference of rock uplift rates between the gorge and its upstream reach corresponds to that of incision rates, which meets the critical condition to sustain a stable knickpoint (as shown in Eq. 11). From this correspondence, we favor the tectonic control hypothesis as the primary mechanism for knickpoint stability of the Yarlung Tsangpo Gorge.

\section{Discussion}

\subsection{Geomorphic evidence of active rock uplift localized around the gorge}

The channel steepness indices show the highest values around the Yarlung Tsangpo Gorge but decrease toward the upstream and downstream reaches, which coincides with rock exhumation rate. Although the pattern of steepness may indicate a tectonic control, some other factors must be discriminated to determine the relationship to rock uplift in this landscape. In what follows we discuss the following potential influences on channel gradients: lithologic resistance, sediment flux, orographically induced variation in precipitation, transient response to changes in base level, and spatial variation in rock uplift. For each, we assess whether the observed pattern of channel gradient can be explained by the process.

\subsubsection{Lithology}

Because lithologic resistance to stream incision can exert a strong control on erosion coefficient $(K)$ (Stock and Montgomery, 1999), varying lithology influences channel gradient and landscape morphology (Moglen and Bras, 1995; Tucker and Slingerland, 1996; Sklar and Dietrich, 2001). In order to assess the potential role of lithologic resistance in influencing channel gradients in the region, we compare the spatial pattern of channel steepness indices with mapped variations in lithology (Fig. 10). The geology was digitized from Chinese geologic maps at a scale of 1:500,000 (Tibet autonomous region geological and mineral exploration and Development Bureau, 1999). 
Downstream of the Yarlung Tsangpo knickpoint, we observe that the transition of lithology from gneiss to conglomerate and granite is close to the transition from the 'red' $\left(k_{s}=8838 \mathrm{~m}\right)$ to 'purple' $\left(k_{s}=1901 \mathrm{~m}\right)$ trunk river segments (Fig. 10), which seems to be a lithological influence on the channel gradient. Another example of lithologic influences on channel gradient occurs along the tributaries of the 'magenta' $\left(k_{s}=746 \mathrm{~m}\right)$ trunk river segments (Fig. 10), where the tributaries flowing through Sinian carbonatite show higher channel steepness $\left(k_{s}>500 \mathrm{~m}\right)$ indices than that through early Permian continental clasolite $\left(k_{s}<500 \mathrm{~m}\right)$.

However, in general, the control of variable lithology on channel profiles is weak. In the great majority of cases, changes in channel steepness do not correspond with mapped lithologic variations (Fig. 10). For example, around the gorge, underlain primarily by gneiss, channel steepness indices decrease from more than $8000 \mathrm{~m}$ (stem) to roughly $1000 \mathrm{~m}$ (tributaries; Fig. 10). This nearly eightfold change takes place across an area of similar bedrock lithology. In the upstream, despite the variable lithologies (e.g., Late Triassic sandstone, Cretaceous granodiorite, and conglomerates), knickpoints (shown as a black cross in Fig. 10) on the tributaries do not nearly correspond to lithologic contacts.

In summary, although variable lithologic resistance can exert a strong control on channel gradients, in this landscape, lithologic effects appear to be limited to local channel reaches. Lithologic variations do not appear to account for the systematic regional patterns in channel steepness indices.

\subsubsection{Precipitation}

A simple consideration of a stream power incision model demonstrates that the increase in erodibility that might accompany greater precipitation would be accompanied by a reduction in channel steepness (Whipple et al., 1999; Roe et al., 2002), as the river is more effective at balancing rock uplift (Kirby et al., 2003). The topographic front along the Himalaya Range, coupled with the southwestern monsoon from the Indian Ocean, induces a steep gradient in precipitation along the Yarlung Tsangpo Gorge (Enklemann et al., 2009; Bookhagen and Burbank, 2010). Figure 11 shows the pattern of mean annual precipitation in the southeastern Tibetan Plateau (time scale: from 1960 to 1990 ; resolution: $0.05^{\circ} \times 0.05^{\circ}$ grid; from National Data Sharing Infrastructure of Earth System Science, www.geodata.cn). Mean annual precipitation varies from $>4000 \mathrm{~mm}$ at the topographic front to $<1000 \mathrm{~mm}$ along the gorge (Fig. 11), with an increase of channel steepness from $<500$ to $8838 \mathrm{~m}$. One might be tempted to interpret the increase in steepness index as a response to decreasing channel erodibility as precipitation decreases. 
However, we argue instead that the systematic patterns of channel steepness in SE Tibet are not the result of changes in precipitation for three reasons. First, the annual rainfall along the gorge is just about a quarter of that at the topographic front, while the steepness increases over 15 times. Second, in the inner land (dry climate, annual rainfall about $250 \mathrm{~mm}$ ), the trunk and tributaries show lower channel steepness values $\left(k_{s}<\right.$ $1000 \mathrm{~m})$. The maximum channel steepness $(8838 \mathrm{~m})$ locates at the gorge but not with the driest climate. Third, steepness indices vary greatly between the trunk channel and its respective tributaries, even across a single climate regime. Thus, the spatial variations in precipitation cannot reflect the pattern of channel steepness.

\subsubsection{Sediment flux}

Owing to variations in grain size, compaction and porosity, and stochastic sediment delivery, the effects of sediment flux on stream profiles are complex (Sklar and Dietrich, 2001). Even for steady-state channel profiles developed under conditions of uniform uplift and lithology, they would depart from a simple detachmentlimited system in two significant ways (Kirby et al., 2003). First, as erosion rates increase owing to an increase in available tools, equilibrium channel gradients should decrease, resulting into a high channel concavity. Second, because the river bed might be protected by sediments from being further eroded, channel erodibility $K$ will decrease. Then, downstream reaches should display a relative increase in gradient (for a given area) as they are forced to steepen in order to maintain a constant erosion rate. The latter effect would reduce the concavity of the downstream reach relative to a detachment-limited model (Whipple and Tucker, 2002).

Along and downstream the Yarlung Tsangpo Gorge, river segments that are typically confined by a steep bedrock channel floor show high concavity indices (Fig. 6C). The trunk channel upstream of the gorge, however, is mantled by sediments and characterized by low concavity (10.02) and steepness values (746 m). Such differences in concavity and steepness indices between the downstream reaches could be caused by sediment storage. Below drilling no. 1, the depth of the fluvial sediment increases until it gets close to the gorge (Fig. 9). Valley-fill sediments (from drilling nos. 3-5) close to the Tsangpo Gorge have coarse grain sizes (including boulders up to $50 \mathrm{~cm}$ in diameter) in the lower half section and fine grain sizes (mainly silt and clay) in the upper half section, which indicates a decrease in stream competency (Wang et al., 2014). During backfilling upstream of the Tsangpo Gorge (Wang et al., 2014), the channel gradient decreases and gets close to a constant value $(\sim 0.1 \%)$, which results in low channel concavity and steepness indices.

The concavity indices of the trunk river are much larger than that of its tributaries, which might be attributed to the difference of drainage area. Figure 12 shows the slope-area analysis of some tributaries of the 
Yarlung Tsangpo River. For the tributaries, the channel gradient varies from about $3 \times 10^{-2}$ to $5 \times 10^{-1}$ within the drainage area of $10^{6}$ to $10^{8} \mathrm{~m}^{2}$ (Fig. 12), which results in an extent of [-3.51, -0.69] (y-axis) and [13.82, 18.42] (x-axis) in the log-transformed slope-area plot. Then, a mean concavity value is derived to be about 0.61. While for the trunk stream, the gradient varies from about $3 \times 10^{-4}$ to $10^{0}$ within the area of $1.5 \times 10^{11}$ to $3.0 \times 10^{11} \mathrm{~m}^{2}$ (Fig. 6C), resulting in an extent of [-8.11, 0] (y-axis) and [25.74, 26.43] (x-axis) in the logtransformed slope-area plot. Then, the mean concavity value is about 11.75 , which is much larger than that of its tributaries. From Eq. (2), the large drainage area can result in low $\chi$ value and high channel steepness. Downstream of the huge knickpoint, the channel steepness indices of the trunk river are much larger than its tributaries, which can be partly because of the distinct difference in drainage area.

However, the systematic patterns of channel gradient along the trunk river and all the tributaries cannot be attributed to downstream changes in sediment flux for two reasons. First, for the tributaries (with drainage area of about $10^{8} \mathrm{~m}^{2}$; Fig. 12), the concavity indices are nearly the same. Despite limited knowledge about the sediment properties among the rivers, a lot of studies have demonstrated an influence of channel substrate property on concavity (Snyder et al., 2000, 2003; Kirby et al., 2003; Wobus et al., 2006). Although a conclusion of similar channel substrate of all the tributaries is unreasonable, we conclude that, in southeastern Tibet, the influence of sediment flux on the channel shape is limited. Second, for the trunk river segments, no consistent relationship exists between profile concavity and drainage area. As shown in Fig. 6C, the concavity indices of the 'blue' (upstream of the gorge, $\theta=10.02, k_{s}=487 \mathrm{~m}$ ) and 'magenta' (downstream of the gorge, $\theta=$ $8.92, k_{s}=746 \mathrm{~m}$ ) reaches are similar despite their difference in drainage area (lower than $2.0 \times 10^{11} \mathrm{~m}^{2}$ and about 2.5-3.0 $\times 10^{11} \mathrm{~m}^{2}$, respectively). While for the gorge, with the rapidest decrease in gradient, the bedrock channel shows the largest concavity index (the absolute value of $\theta$ is over 400; Fig. 6C). Such distinct variation in $\theta$ shows the strong geographic relationship of the trunk river profile concavity to the plateau margin, suggesting that channel gradients along the trunk river reflect an external forcing that is geographically restricted rather than drainage area dependent.

\subsubsection{Rock uplift}

In southeastern Tibet, the geomorphic response time of the landscape to temporary changes in tectonics and climate is short, $<0.5 \mathrm{Ma}$ (Chen et al., 2008), which means that any transient signal (e.g., base level fall or escarpment retreat) migrates upstream rapidly. Supposing a control of transient signal, channels would be steepest near the drainage divide and equilibrated in their downstream reaches, as observed along Gondawanan 
continental escarpments (Seidl et al., 1996; Weissel and Seidl, 1998). Such a pattern, however, is inconsistent with the high channel steepness observed just along and near the gorge (Figs. 6D and 11).

Given the above arguments that lithology, sediment flux, orographic precipitation, and transient channel conditions cannot sufficiently explain the observed pattern of channel profiles, we reason that the spatial distribution of high channel steepness most likely reflects active rock uplift along the Yarlung Tsangpo Gorge. From the spatial distribution of stream steepness (Figs. 11 and 12), we can infer that the zone of high rock uplift is apparently localized around the gorge, a region about $60 \mathrm{~km}$ wide in the east Himalaya syntaxis. Upstream and downstream of the gorge, rock uplift appears to be decreasing rapidly.

In our interpretation, the relatively high steepness of the gorge and its tributaries and the low steepness of the upstream and downstream reaches reflect adjustments of channel gradient in response to these spatial variations in rock uplift rate in southeastern Tibet. The good linear fit of the $\chi-z$ plot gives a mean steepness value $(8838 \mathrm{~m}$ ) of the gorge (Fig. 6B). The high channel concavity (Fig. 6C) and the distance-steepness plot (Fig. 6D), however, reflect rock uplift rates that are decreasing from the knickpoint toward the mountain front.

Despite the lack of quantitative relationship between channel steepness and rock uplift rate in this landscape, we can discern several lines of evidence that lend support to our argument that the distribution of channel gradients reflect underlying patterns in differential rock uplift. First, the highest mountain peaks, Namcha Barwa and Gyala Peri, are located on the south and north sides of the gorge, respectively. The topography decreases rapidly in the plateau margin, which is consistent with the variation of channel steepness. Second, thermochronologic research shows the youngest annealing ages (Zircon $\mathrm{U}-\mathrm{Th} / \mathrm{He}$ and Biotite 40Ar/ $39 \mathrm{Ar})$ are $<2 \mathrm{Ma}$ around the gorge, indicating the rapidest exhumation rates. Numerical modelling indicates that the rock uplift rate here can be up to $5 \mathrm{~mm} / \mathrm{a}$, beyond the rate in the surrounding zones. In addition, the upstream tributaries can be divided into two segments with different channel steepness (Figs. 12A and 13) by the so-called slope-break knickpoints. These knickpoints, regardless of the channel substrate type, locate at the same elevation of about $3500 \mathrm{~m}$ (Fig. 13). Schmidt et al. (2015) concluded that the scenario was the result of upstream knickpoint migration initiated near the gorge. The pattern of long-term exhumation across the plateau margin is again consistent with that of active rock uplift inferred from stream steepness. Thus, while the quantitative relation between rock uplift and channel steepness remains uncertain, we conclude that differential rock uplift exerts a first-order control on channel profiles in this landscape.

In our interpretation, the pattern of higher steepness values around the gorge and the lower ones in the inner land and topographic front reflects the spatial variations in rock uplift rate in southeastern Tibet. The 
pattern of channel steepness shows that rock uplift rate decreases from the gorge toward the upstream and downstream areas. Based on the analysis above, the pattern of channel steepness shows that the rapid rock uplift is restricted around the gorge.

\subsection{Stream power parameters in our model}

In our model, erosional parameters in the stream power model (channel concavity $\theta$, river erodibility $K$ ) are calculated to determine the incision rate in the gorge.

We chose a $\theta$ value that minimizes the elevation scatter in the $\chi-z$ curves as the reference concavity. In addition, two or more methods have been proposed to determine the parameter. Kirby et al. (2003) utilized a mean $\theta$ value of all river segments in their study area as the reference concavity. Rudge et al. (2015) determined the erosional parameter values in the stream power model (e.g., $m$ and $n$ ) via joint inversion of drainage patterns. However, the concavity indices of all river segments (including trunk river and its tributaries) falls in a wide range of $<1$ to $>400$ (Figs. $6 \mathrm{C}$ and 12; much larger than the $\theta$ range in Longmen Shan, Kirby et al., 2003), which makes it somewhat unreasonable to determine the mean value directly. In addition, joint inversion may be time consuming in such a large area.

The method described in section 3.1 has already been used by Goren et al. (2014a), Willett et al. (2014), and Yang et al. (2015). In their work, nearly all streams in a drainage basin are chosen to generate $\chi$-z plots. Here, we chose some in the whole Yarlung Tsangpo drainage network, which can be appropriate for two reasons. First, plenty of the streams (more than 200) are used in calculation. These tributaries are all selected

randomly. Secondly, the reference concavity $(\theta=0.5)$ is close to the result (0.42) of Schmidt et al. (2015) and in the range of concavity indices of the tributaries (Fig. 12). A limited difference is allowed for the complex lithology and climate in the SE Tibetan Plateau.

In this contribution, river erodibility $K$ is derived from a linear regression between channel steepness and rock exhumation rate. The exponent of gradient $n$ is assumed to be 1 for the good linear relationship. The theoretical relationship between channel steepness and river erosion rate is shown in Eq. (12). In fact, a linear (Safran et al., 2005; Harkins et al., 2007) or power-law (Ouimet et al., 2009; Cyr et al., 2010; DiBiase et al., 2010) scaling relationship between $k_{s}$ and catchment-wide erosion rate derived from river sediment ${ }^{10} \mathrm{Be}$ concentration has already been found in many areas.

In the Inyo Mountains, Goren et al. (2014a) determined the channel erodibility by dividing rock exhumation rate (from Zircon U-Th/He age) by local channel steepness. In the SE Tibetan Plateau, despite 
limited work on the catchment-wide erosion rate, a lot of rock sample annealing ages have been published. We determined rock exhumation rate from Zircon U-Th/He age and program AGE2EDOT. To get a mean channel concavity, we did a linear regression between local channel steepness and exhumation rate, which is similar to Goren et al. (2014a). The derived mean erodibility $K$ also shares a similar magnitude of $10^{-7}$ with the result determined from knickpoint celerity modeling (a linear model, Schmidt et al., 2015).

Based on the gorge drainage area, erodibility $K$, and mean channel slope, we derived the mean stream incision rate $(5.83 \pm 0.35) \times 10^{-3} \mathrm{~m} / \mathrm{a}$ at the gorge. In addition, to estimate spatial patterns of bedrock incision rates, Finnegan et al. (2005) proposed an expression for scaling the steady-state channel width as a function of discharge, channel slope, channel roughness, and width-to-depth ratio. The fluvial incision rate along the gorge falls in the range of $[1,10] \times 10^{-3} \mathrm{~m} / \mathrm{a}$ (Finnegan et al., 2008), which results in a mean value of $5.5 \times 10^{-3} \mathrm{~m} / \mathrm{a}$, approximately. Thus, the correspondence (channel concavity, erodibility, and mean incision rate) between previous studies and our contribution may also show the reasonability of our work.

\subsection{Potential role of glacier dams on the stability of the Yarlung Tsangpo Gorge}

Based on the pattern of channel steepness, we derive spatially variant rock uplift in the SE Tibetan Plateau with the highest rates restricted in the zone around the gorge. According to a simple knickpoint migration model, we draw a critical condition to sustain a stable knickpoint and a conclusion that differential tectonic uplift can be the primary mechanism for the stability of the Yarlung Tsangpo Gorge.

However, the potential role of glacier dams on major rivers in sustaining a stable knickpoint cannot be neglected. Montgomery et al. (2004) recognized repeated Holocene glacial damming of the Yarlung Tsangpo above its gorge and similar blockages occurring on its major tributaries. Korup and Montgomery (2008) mapped 260 moraine dams formed by glaciers flowing from tributary basins that blocked the Yarlung Tsangpo River and inferred the Holocene equilibrium line altitude (ELA) from locations of major moraine dams. Combining hypsometric curves of river-channel elevations with contributing catchment areas, they found that $40-60 \%$ of this drainage network might have been above the Holocene ELA and that the distinct kink in the drainage network hypsometry at $\sim 4200$ m coincided well with the reconstructions of the Holocene ELA. According to the geomorphic evidence, conclusions were made by Korup and Montgomery (2008) that ELA depressions during the Holocene glacial maxima blocked major rivers and that headward knickpoint migration in these bedrock rivers has either stalled or not yet progressed any farther into the Tibetan plateau. 
In addition, a growing body of work has identified the importance of large floods in canyon formation and evolution (Lamb et al., 2014; Anton et al., 2015; Baynes et al., 2015). Baynes et al. (2015) showed that the high magnitude, low-frequency flood events can dominate the long-term evolution of landscapes. Montgomery et al. (2004) identified a potential role of post-glacial megafloods in the formation and evolution of the Yarlung Tsangpo Gorge.

Nevertheless, these studies on the influence of glaciers or megafloods lacked accurate timing constraints on the formation of the Yarlung Tsangpo Gorge. Korup and Montgomery (2008) conducted a good study on the Holocene equilibrium line altitude, which can show a significant role of Holocene glacier dams on sustaining the huge knickpoint in a short time scale. Cautiousness should be taken when considering the effect of glaciers in a relatively long time scale. Provenance studies from the Himalayan foreland, however, indicate that a connection between the Yarlung Tsangpo and Brahmaputra River was already established before the middle Miocene (Cina et al., 2009; Chirouze et al., 2013; Lang and Huntington, 2014), emphasizing the stability of the gorge. The young zircon $(\mathrm{U}-\mathrm{Th}) / \mathrm{He}$ cooling ages $(<3 \mathrm{Ma})$ and high river incision rates $(1-10 \mathrm{~mm} / \mathrm{a})$ are all spatially colocated along the Yarlung Tsangpo Gorge, which demonstrates that the Yarlung Tsangpo knickpoint has long been stationary since the late Pliocene or early Pleistocene (Finnegan et al., 2008). Our analysis shows that localized tectonic uplift can better explain stability of the Tsangpo Gorge, based on the assumption in section 4.1. As a result, fluvial incision into the Tibetan Plateau is impeded, preserving the plateau's high topography. We conclude that tectonic control plays a key role in sustaining high topography throughout a long time scale.

\section{Conclusions}

In this contribution, we try to support the viewpoint that localized rock uplift around the gorge can be the primary mechanism for knickpoint stability of the Yarlung Tsangpo Gorge.

First, via slope-area analysis and the integral approach, we quantified the pattern of channel steepness

(including the trunk river and its tributaries) in the southeastern Tibetan Plateau. The channel steepness shows higher values around the gorge but lower ones in the upstream and downstream reaches. Such a pattern indicates that the active rock uplift is restricted in the zone around the Yarlung Tsangpo Gorge.

Then, we tested if the localized rock uplift could sustain the stability of the gorge (tectonic control). We derived a general knickpoint migration velocity (horizontal) formula allowing spatially variant rock uplift. A 
critical condition for maintaining a stable knickpoint concluded that the difference of incision rates in the downstream and upstream reaches of the knickpoint should match that of rock uplift. We calculated the parameters in the critical condition (e.g., rock exhumation rates, channel steepness, and rock erodibility of the Yarlung Tsangpo Gorge). Combining these parameters, we obtained the river incision rate at the gorge. Finally, we compared the incision rates and the rock uplift rates along the gorge and the upstream reach and found that the critical condition is met. Therefore, we favor the tectonic control hypothesis as the primary mechanism for knickpoint stability of the Yarlung Tsangpo Gorge.

\section{Acknowledgements}

We thank Amanda McDowell and Rasia Canete Blazquez (Oregon State University) for revision in English writing. Comments provided by four anonymous reviewers and the editor helped to clarify and improve the manuscript. We are grateful for the grants from the Strategic Priority Research Program of the Chinese Academy of Sciences (XDB03020200) and from the National Science Foundation of China (41272215, 41272196).

\section{References}

Anders, A. M., Roe, G. H., Hallet, B., Montgomery, D.R., Finnegan, N. J., Putkonen, J., 2006. Spatial patterns of precipitation and topography in the Himalaya. In: Willett, S. D., Hovius, N., Brandon, M. T., Fisher, D. (Eds.), Tectonics, Climate, and Landscape Evolution. Geol. Soc. Am. Bull. Special Paper 398, 39-53, doi: $10.1130 / 2006.2398(03)$.

Anton, L., Mather, A.E., Stokes, M., Muñoz-Martin, A., Vicente, G.D., 2015. Exceptional river gorge formation from unexceptional floods. Nat. Commun. 6, 7963, doi:10.1038/ncomms8963.

Batt, G.E., Brandon, M.T., 2002. Lateral thinking: 2-D interpretation of thermochronology in convergent orogenic settings. Tectonophysics 349, 185-201, doi:10.1016/S0040-1951(02)00053-7.

Baynes, E.R.C., Attal, M., Niedermann, S., Kirstein, L.A., Dugmore, A.J., Naylor, M., 2015. Erosion during extreme flood events dominates Holocene canyon evolution in northeast Iceland. P. Natl. Acad. Sci. USA, 112, 2355-2360, doi: 10.1073/pnas.1415443112. 
Beaumont, C., Jamieson, R.A., Nguyen, M.H., Lee, B., 2001. Himalayan tectonics explained by extrusion of a low-viscosity crustal channel coupled to focused surface denudation. Nature, 414, 738-742, doi: $10.1038 / 414738$ a.

Berlin, M.M., Anderson, R.S., 2007. Modeling of knickpoint retreat on the Roan Plateau, western Colorado. J. Geophys. Res. 112, F03S06, doi: 10.1029/2006JF000553.

Bookhagen, B., Burbank D.W., 2010. Toward a complete Himalayan hydrological budget: Spatiotemporal distribution of snowmelt and rainfall and their impact on river discharge. J. Geophys. Res. 115, F03019, doi:10.1029/2009JF001426.

Booth, A.L., Chamberlain, C.P., Kidd, W.S.F., Zeitler, P.K., 2009. Constraints on the metamorphic evolution of the eastern Himalayan syntaxis from geochronologic and petrologic studies of Namche Barwa. Geol. Soc. Am. Bull. 121, 385-407, doi: 10 .1130/B26041 .1.

Bracciali, L., Parrish, R.R., Najman, Y., Smye, A., Carter, A., Wijbrans, J.R., 2016. Plio-Pleistocene exhumation of the eastern Himalayan syntaxis and its domal'pop-up'. Earth-Science Reviews 160, 350385, doi: 10.1016/j.earscirev.2016.07.010.

Braun, J., Beek, P.V.D., Batt, G., 2006. Quantitative Thermochronology Numerical Methods for the Interpretation of Thermochronological Data. Cambridge Univ. Press, NY, pp. 33-48.

Burbank, D.W., Blythe, A.E., Putkonen, J., Pratt-Sitaula, B., Gabet, E., Oskin, M., Barros, A., Ojha, T.P., 2003. Decoupling of erosion and precipitation in the Himalayas. Nature 426, 652-655, doi:10.1038/ nature 02187.

Champagnac, J.-D., Molnar, P., Sue, C., Herman, F., 2012. Tectonics, climate, and mountain topography. J. Geophys. Res., 117, B02403, doi: 10.1029/2011JB008348.

Chen, J.J., Ji, J.Q., Yu, S.L., 2008. Quantitative analysis of geomorphologic response time-scale of the Yarlung Zangbo Great Canyon. Quaternary Science 28(2), 264-272 (in Chinese with English abstract).

Chirouze, F., Huyghe, P., van der Beek, P., Chauvel, C., Chakraborty, T., Dupont-Nivet, G., Bernet, M., 2013. Tectonics, exhumation, and drainage evolution of the eastern Himalaya since $13 \mathrm{Ma}$ from detrital geochemistry and thermochronology, Kameng River section, Arunachal Pradesh. Geol. Soc. Am. Bull. 125, 523-538, doi:10.1130/B30697.1.

Cina, S.E., Yin, A., Grove, M., Dubey, C.S., Shukla, D.P., Lovera, O.M., Kelty, T.K., Gehrels, G.E., Foster, D.A.. 2009. Gangdese arc detritus within the eastern Himalayan Neogene foreland basin: Implications for 
the Neogene evolution of the Yalu-Brahmaputra River system. Earth Planet. Sci. Lett. 285, 150-162, doi: 10.1016/j.eps1.2009.06.005.

Clark, M.K., Royden, L.H., Whipple, K.X., Burchfiel, B.C., Zhang, X., Tang, W., 2006. Use of a regional, relict landscape to measure vertical deformation of the eastern Tibetan Plateau. J. Geophys. Res. 111, F03002, doi: 10.1029/2005JF000294.

Cook, K.L., Turowski, J.M., Hovius, N., 2013. A demonstration of the importance of bedload transport for fluvial bedrock erosion and knickpoint propagation. Earth Surf. Process. Landforms 38, 683-695, doi: 10.1002/esp.3313.

Cyr, A.J., Granger, D.E., Olivetti, V., Molin, P., 2010. Quantifying rock uplift rates using channel steepness and cosmogenic nuclide-determined erosion rates: examples from northern and southern Italy. Lithosphere 2(3), 188-198, doi:10.1130/L96.1.

DiBiase, R.A., Whipple, K.X., Heimsath, A.M., Ouimet, W.B., 2010. Landscape form and millennial erosion rates in the San Gabriel Mountains, CA. Earth Planet. Sci. Lett. 289(1), 134-144, doi:10.1016/j.epsl. 2009.10.036.

DiBiase, R.A., Whipple, K.X., Lamb, M.P., Heimsath, A.M., 2015. The role of waterfalls and knickzones in controlling the style and pace of landscape adjustment in the western San Gabriel Mountains, California. Geol. Soc. Am. Bull. 127, 539-559, doi: 10.1130/B31113.1.

Enkelmann, E., Zeitler, P.K., Pavlis, T.L., Garver, J.I., Ridgway, K.D., 2009. Intense localized rock uplift and erosion in the St Elias orogen of Alaska. Nature Geosci. 2(5), 360-362, doi: 10.1038/ngeo502.

Enkelmann, E., Ehlers, T.A., Zeitler, P.K., Hallet, B., 2011. Denudation of the Namche Barwa anti form, eastern Himalaya. Earth Planet. Sci. Lett. 307, 323-333, doi:10.1016/j.eps1.2011.05.004.

Finnegan, N.J., Roe, G., Montgomery, D.R., Hallet, B., 2005. Controls on the channel width of rivers: Implications for modelling fluvial incision of bedrock. Geology 33, 229-232, doi: 10.1130/G21171.1.

Finnegan, N.J., Hallet, B., Montgomery, D.R., Zeitler, P.K., Stone, J.O., Anders, A.M., Liu, Y., 2008. Coupling of rock uplift and river incision in the Namche Barwa-Gyala Peri massif, Tibet. Geol. Soc. Am. Bull. 120, 142-155, doi: 10.1130/B26224.1.

Flint, J.J., 1974. Stream gradient as a function of order, magnitude, and discharge. Water Resour. Res. 10(5), 969-973, doi:10.1029/WR010i005p00969.

Fox, M., Goren, L., May, D.A., Willett, S.D., 2014. Inversion of fluvial channels for paleorock uplift rates in Taiwan. J. Geophys. Res.-Earth 119, 1853-1875, doi:10.1002/2014JF003196. 
Fox, M., Bodin, T., Shuster, D.L., 2015. Abrupt changes in the rate of Andean Plateau uplift from reversible jump Markov Chain Monte Carlo inversion of river profiles. Geomorphology 238, 1-14, doi:10.1016/ j.geomorph.2015.02.022.

Gong, J.F., Ji, J.Q., Chen, J.J., Sang, H.Q., Li, B.L., Liu, Y.D., Han, B.F., 2008. The ${ }^{40} \mathrm{Ar} /{ }^{39} \mathrm{Ar}$ geochronology studies of rocks in eastern Himalaya syntaxis. Acta Petrologica Sinica 24(10), 2255-2272, doi: 1000-0569/2008/024(10)-2255-72 (in Chinese with English abstract).

Gong, J.F., Ji, J.Q., Zhou, J., Tu, J.Y., Sun, D.X., Zhong, D.L., Han, B.F., 2015. Late Miocene thermal evolution of the eastern Himalayan syntaxis as constrained by biotite 40Ar/39Ar thermochronology. The Journal of Geology 123, 369-384, doi: 10.1086/682951.

Goren, L., Fox, M., Willett, S.D., 2014a. Tectonics from fluvial topography using formal linear inversion: Theory and applications to the Inyo Mountains, California. J. Geophys. Res.-Earth 119, 1651-1681, doi: 10.1002/2014JF003079.

Goren, L., Willett, S.D., Herman, F., Braun, J., 2014b. Coupled numerical-analytical approach to landscape evolution modeling. Earth Surf. Process. Landforms 39,522-545, doi: 10.1002/esp.3514.

Grimaud, J.-L., Paola, C., Voller, V., 2016. Experimental migration of knickpoints: influence of style of baselevel fall and bed lithology. Earth Surf. Dynam. 4, 11-23, doi:10.5194/esurf-4-11-2016.

Harkins, N., Kirby, E., Heimsath, A., Robinson, R., Reiser, U., 2007. Transient fluvial incision in the headwaters of the Yellow River, northeastern Tibet, China. J. Geophys. Res. 112, F03S04, doi: 10.1029/2006JF000570.

Haviv, I., Enzel, Y., Whipple, K.X., Zilberman, E., Matmon, A., Stone, J., Fifield, K.L., 2010. Evolution of vertical knickpoints (waterfalls) with resistant caprock: Insights from numerical modelling. J. Geophys. Res.-Earth 115(F3), F03028, doi:10.1029/2008JF001187.

Howard, A.D., Kerby, G., 1983. Channel changes in badlands. Geol. Soc. Am. Bull. 94(6), 739-752, doi: 10.1130/0016-7606(1983)94<739:CCIB>2.0.CO;2.

Hu, X., Pan, B., Kirby, E., Li, Q., Geng, H., Chen, J., 2010. Spatial differences in rock uplift rates inferred from channel steepness indices along the northern flank of the Qilian Mountain, northeast Tibetan Plateau. Chinese Sci. Bull. 55(23), 2329-2338, doi: 10.1007/s11434-010-4024-4

Humphrey, N.F., Konrad, S.K.. 2000. River incision or diversion in response to bedrock uplift. Geology 28, 43-46, doi: 10.1130/0091-7613(2000)28<43:RIODIR>2.0.CO;2. 
Kang, W.J., 2014. Thermochronological and Geomorphologic Evidence for Division of Differential Tectonic

Uplifting of the Mt. Namche Barwa. M.S. Thesis, Institute of Geology China Earthquake Administration, Peiking, China (in Chinese with English Abstract).

Kirby, E., Whipple, K.X., 2001. Quantifying differential rock-uplift rates via stream profile analysis. Geology 29, 415-418, doi: 10.1130/0091-7613(2001)029<0415:QDRURV>2.0.CO;2.

Kirby, E., Whipple, K.X., 2012. Expression of active tectonics in erosional landscapes. J. Struct. Geol. 44, 54-75, doi: 10.1016/j.jsg.2012.07.009.

Kirby, E., Whipple, K.X., Tang, W., Chen, Z., 2003. Distribution of active rock uplift along the eastern margin of the Tibetan Plateau: inferences from bedrock river profiles. J. Geophys. Res. 108, 2217-2240, doi: 10.1029/2001JB000861.

Kirby, E., Johnson, C., Furlong, K., Heimsath, A., 2007. Transient channel incision along Bolinas Ridge, California: Evidence for differential rock uplift adjacent to the San Andreas fault, J. Geophys. Res. 112, F03S07, doi:10.1029/2006JF000559.

Korup, O., Montgomery, D.R., 2008. Tibetan plateau river incision inhibited by glacial stabilization of the Tsangpo Gorge. Nature 455: 786-790, doi:10.1038/nature07322.

Lamb, M.P., Mackey, B.H., Farley, K.A., 2014. Amphitheater-headed canyons formed by megaflooding at Malad Gorge, Idaho. P. Natl. Acad. Sci. USA 111, 57-62, doi: 10.1073/pnas.1312251111.

Lang, K.A., Huntington, K.W., 2014. Antecedence of the Yarlung-Siang-Brahmaputra River, eastern Himalaya. Earth. Planet. Sci. Lett. 397, 145-158, doi:10.1016/j.eps1.2014.04.026.

Lang, K.A., Huntington, K.W., Burmester, R., Housen, B., 2016. Rapid exhumation of the eastern Himalayan syntaxis since the late Miocene. Geol. Soc. Am. Bull. B31419.1, doi: 10.1130/B31419.1.

Liang, S., Gan, W., Shen, C., Xiao, G., Liu, J., Chen, W., Ding, X., Zhou, D., 2013. Three-dimensional velocity field of present-day crustal motion of the Tibetan Plateau derived from GPS measurements. J. Geophys. Res.- Sol. Ea. 118, 5722-5732, doi:10.1002/2013JB010503.

Liu, Y., Zhong, D., 1997. Petrology of high-pressure granulites from the eastern Himalayan syntaxis. J. Metamorph. Geol. 15, 451-466, doi:10.1111/j.1525-1314.1997.00033.x.

Mackey, B.H., Scheingross, J.S., Lamb, M.P., Farley, K.A., 2014. Knickpoint formation, rapid propagation, and landscape response following coastal cliff retreat at the last interglacial sea-level highstand: Kaua'i, Hawai'i. Geol. Soc. Am. Bull. 126, 925-942, doi: 10.1130/B30930.1. 
Moglen, G.E., Bras, R.L., 1995. The effect of spatial heterogeneities on geomorphic expression in a model of basin evolution. Water Resour. Res. 31(10), 2613 - 2623, doi:10.1029/95WR02036.

Molnar, P. England, P., 1990. Late Cenozoic uplift of mountain ranges and global climate change: chicken or egg? Nature 346, 29-34, doi:10.1038/346029a0.

Molnar, P., Anderson, R.S., Anderson, S.P., 2007. Tectonics, fracturing of rock, and erosion J. Geophys. Res. 112, F03014, doi: 10.1029/2005JF000433.

Montgomery, D.R., Hallet, B., Liu, Y., Finnegan, N., Anders, A., Gillespie, A., Greenberg, H.M., 2004. Evidence for Holocene megafloods down the Tsangpo River gorge, southeastern Tibet. Quaternary Res. 62, 201-207, doi:10.1016/j.yqres.2004.06.008.

Naeser, C.W., 1979. Thermal history of sedimentary basins: fission-track dating of subsurface rocks. In: Scholle P.A., Schluger, P.R. (Ed.), Aspects of Diagenesis. Society of Economic Paleontologists and Mineralogists, Tulsa, Oklahoma, pp. 109-112, doi: 10.2110/pec.79.26.0109.

Nie, J.J., 2015. Thermochronology research of climate-erosion-tectonic in the eastern Himalayan syntaxis. Ph.D. Dissertation, Peiking Univ., Peiking, China (in Chinese with English Abstract).

Ouimet, W.B., Whipple, K.X., Granger, D.E., 2009. Beyond threshold hillslopes: channel adjustment to baselevel fall in tectonically active mountain ranges. Geology 37(7), 579-582, doi:10.1130/G30013A.1.

Perron, J.T., Royden, L., 2013. An Integral Approach to Bedrock River Profile Analysis. Earth Surf. Process. Landforms 38, 570-576, doi: 10.1002/esp.3302.

Pritchard, D., Roberts, G.G., White, N.J., Richardson, C.N., 2009. Uplift histories from river profiles. Geophys. Res. Lett. 36, L24301, doi:10.1029/2009GL040928.

Reiners, P.W., Brandon, M.T., 2006. Using Thermochronology to understand Orogenic Erosion. Annu. Rev. Earth Planet. Sci. 34, 419-466, doi: 10.1146/annurev.earth.34.031405.125202.

Roe, G.H., Montgomery, D.R., Hallet, B., 2002. Effects of orographic precipitation variations on the concavity of steady-state river profiles. Geology 30(2), 143-146, doi: 10.1130/0091-7613(2002)030<0143:EOOPVO>2.0.CO;2.

Rosenbloom, N.A., Anderson, R.S., 1994. Hillslope and channel evolution in a marine terraced landscape, Santa Cruz, California. J. Geophys. Res. 99, 14013-14030, doi: 10.1029/94JB00048.

Royden, L., Perron, J.T., 2013. Solutions of the Stream Power Equation and Application to the Evolution of River Longitudinal Profiles. J. Geophys. Res.- Earth 118(2), 497-518, doi:10.1002/jgrf.20031. 
Rudge, J.F., Roberts, G.G., White, N.J., Richardson, C.N., 2015. Uplift histories of Africa and Australia from linear inverse modeling of drainage inventories. J. Geophys. Res.-Earth 120, 894-914, doi: 10.1002/2014JF003297.

Safran, E.B., Bierman, P.R., Aalto, R., Dunne, T., Whipple, K., Caffee, M., 2005. Erosion rates driven by channel network incision in the Bolivian Andes. Earth Surf. Process. Landforms 30(8), 1007-1024, doi: 10.1002/esp.1259.

Schmidt, J.L., Zeitler, P.K., Pazzaglia, F.J., Tremblay, M.M., Shuster, D.L., Fox, M., 2015. Knickpoint evolution on the Yarlung river: Evidence for late Cenozoicuplift of the southeastern Tibetan plateau margin. Earth Planet. Sci. Lett. 430, 448-457, doi:10.1016/j.epsl.2015.08.041.

Seidl, M.A., Weissel, J.K., Pratson, L.F., 1996. The kinematics and pattern of escarpment retreat across the rifted continental margin of SE Australia. Basin Res. 8(3), 301-316, doi:10.1046/j. 1365-2117.1996.00266.x.

Seward, D., Burg, J.P., 2008. Growth of Namcha Barwa Syntaxis and associated evolution of the Tsangpo Gorge: Constraints from structural and thermochronological data. Tectonophysics 451(1-4), 282-289, doi: 10.1016/j.tecto.2007.11.057.

Sklar, L.S., Dietrich, W.E., 2001. Sediment and rock strength control on river incision into bedrock. Geology 29(12), 1087-1090, doi:10.1130/0091-7613(2001)029<1087:SARSCO>2.0.CO;2.

Snyder, N.P., Whipple, K.X., Tucker, G.E., Merritts, D.J., 2000. Landscape response to tectonic forcing: Digital elevation model analysis of stream profiles in the Mendocino triple junction region, northern California. Geol. Soc. Am. Bull. 112, 1250-1263, doi: 10.1130/0016-7606(2000)112<1250:LRTTFD $>2.0 . C O ; 2$.

Snyder, N.P., Whipple, K.X., Tucker, G.E., Merritts, D.J., 2003. Channel response to tectonic forcing: field analysis of stream morphology and hydrology in the Mendocino triple junction region, northern California. Geomorphology 53, 97-127, doi:10.1016/S0169-555X(02)00349-5.

Stock, J.D., Montgomery, D. R., 1999. Geologic constraints on bedrock river incision using the stream power law. J. Geophys. Res.- Sol. Ea. 104(B3), 4983 - 4993, doi:10.1029/98JB02139.

Sun, D.X., 2014. The detrital mineral low-thermochronology method and exhumation history of catchments in Southeastern Tibet. Ph.D. Dissertation, Peiking Univ., Peiking, China (in Chinese with English Abstract).

Tagami, T., Shimada, C., 1996. Natural long-term annealing of the zircon fission track system around a granitic pluton. J. Geophys. Res. 101, 8245-8256, doi: 10.1029/95JB02885. 
Tagami, T., Hurford, A.J., Carter, A., 1995. Natural long-term annealing of the zircon fission track system in Vienna Basin deep borehole samples; constraints upon the partial annealing zone and closure temperature. Chem. Geol. 130, 147-157, doi:10.1016/0009-2541(96)00016-2.

Tibet autonomous region geological and mineral exploration and Development Bureau, 1999. 1:500,000 Digital geological map of Tibet. (A database from http://geodata.ngac.cn/Document/Map.aspx? MapId=EC7E1A7A76931954E0430100007F182E)

Tucker, G.E., Slingerland, R., 1996. Predicting sediment flux from fold and thrust belts. Basin Res. 8(3), 329 349, doi:10.1046/j.1365-2117.1996.00238.x.

Wagner, G. A., 1979. Correction and interpretation of fission track ages, in: Lectures in Isotope Geology, edited by: Jäger E., Hunziker, J. C., Springer-Verlag Berlin Heidelberg 170-177, doi: 10.1007/978-3-642-67161-6_11.

Wang, E.Q., Chen, L.Z., Chen, Z.L., 2002. Tectonic and climatic element-controlled evolution of the Yarlung Zangbu River in Southeast Tibet. Quaternary Sciences 22, 365-373, doi: 10.3321/j.issn: 1001-7410.2002.04.009 (in Chinese with English Abstract).

Wang, P., Scherler, D., Liu-Zeng, J., Mey, J., Avouac, J.P., Zhang, Y., Shi, D.G., 2014. Tectonic control of Yarlung Tsangpo Gorge revealed by a buried canyon in Southern Tibet. Science 346, 978-981, doi: 10.1126/science. 1259041 .

Weissel, J.K., Seidl, M.A., 1998. Inland propagation of erosional escarpments and river profile evolution across the southeast Australian passive continental margin. In: Tinkler, K.J., Wohl, E.E. (Eds.), Rivers Over Rock, Fluvial Processes in Bedrock Channels. Geophysical Monograph Series 107, AGU, Washington DC, pp. 189-206, doi:10.1029/GM107p0189.

Whipple, K.X., Tucker, G. E., 2002. Implications of sediment-flux-dependent river incision models for landscape evolution. J. Geophys. Res.- Sol. Ea.107(B2), 2039, doi:10.1029/2000JB000044.

Whipple, K.X., Kirby, E., Brocklehurst, S. H., 1999. Geomorphic limits to climate-induced increases in topographic relief. Nature 401(6748), 39-43, doi:10.1038/43375.

Whittaker, A.C., Boulton, S.J., 2012. Tectonic and climatic controls on knickpoint retreat rates and landscape response times. J. Geophys. Res. 117, F02024, doi:10.1029/2011JF002157.

Whittaker, A.C., Cowie, P.A., Attal, M., Tucker, G.E., Roberts, G.P., 2007. Contrasting transient and steadystate rivers crossing active normal faults: New field observations from the Central Apennines, Italy. Basin Res. 19(4), 529-556, doi:10.1111/j.1365-2117.2007.00337.x. 
Willett, S.D., 1999. Orogeny and orography: the effects of erosion on the structure of mountain belts. J. Geophys. Res. 104, 28957-28981, doi: 10.1029/1999JB900248.

Willett, S.D., McCoy, S.W., Perron, J.T., Goren, L., Chen, C.Y., 2014. Dynamic reorganization of river basins. Science 343, 1248765, doi: 10.1126/science.1248765.

Wobus, C., Whipple, K.X., Kirby, E., Snyder, N., Johnson, J., Spyropolou, K., Crosby, B., Sheehan, D., 2006. Tectonics from topography: Procedures, promise, and pitfalls. In: Willett, S.D., Hovius, N., Brandon, M.T., Fisher, D.M. (Eds.), Tectonics, climate, and landscape evolution. Geological Society of America Special Paper 398, Penrose Conference Series, pp. 55-74, doi: 10.1130/2006.2398(04).

Wolf, R.A., Farley, K.A., Silver, L.T., 1996. Helium diffusion and low-temperature thermochronometry of apatite. Geochim. Cosmochim. Acta 60, 4231-4240, doi:10.1016/S0016-7037(96)00192-5.

Yang, R., Willett, S.D., Goren, L., 2015. In situ low-relief landscape formation as a result of river network disruption. Nature 520, 526-529, doi:10.1038/nature14354.

Yu, X.J., Ji, J.Q., Gong, J.F., Sun, D.X., Qing, J.C., Wang, L.N., Zhong, D.L., Zhang, Z. C., 2011. Evidences of rapid erosion driven by climate in the YarlungZangbo (Tsangpo) Great Canyon, the eastern Himalayan syntaxis. Chin. Sci. Bull. 56, 1123-1130, doi:10.1007/s11434-011-4419-x.

Zaun, P.E., Wagner, G.A., 1985. Fission track stability in zircons under geological conditions. Nucl. Tracks Rad. Meas. 10, 303-307, doi:10.1016/0735-245X(85)90119-X.

Zeitler, P.K., Koons, P.O., Bishop, M.P., Chamberlain, C.P., Craw, D., Edwards, M.A., Hamidullah, S., Jan, M.Q., Khan, M.A., Khattak, M.U.K., Kidd, W.S.F., Mackie, R.L., Meltzer, A.S., Park, S.K., Pecher, A., Poage, M.A., Sarker, G., Schneider, D.A., Seeber, L., Shroder, J.F., 2001. Crustal reworking at Nanga Parbat, Pakistan: Metamorphic consequences of thermal-mechanical coupling facilitated by erosion. Tectonics 20, 712-728, doi: 10.1029/2000TC001243.

Zeitler, P.K., Pavlis, T.L., Garver, J.I., Ridgway, K.D., Enkelmann, E., 2009. Intense localized rock uplift and erosion in the St Elias orogen of Alaska. Nat. Geoscience 2, 360-363, doi:10.1038/ngeo502.

Zeitler, P.K., Meltzer, A.S., Brown, L., Kidd, W.S., Lim, C., Enkelmann, E., 2014. Tectonics and topographic evolution of Namche Barwa and the easternmost Lhasa block, Tibet. Geol. Soc. Am. Bull. Special Papers 507, 23-58, doi: 10.1130/2014.2507 (02).

Zhang, H.P., Zhang, P.Z., Fan, Q.C., 2011. Initiation and recession of the fluvial knickpoints: A case study from the Yalu River-Wangtian'e volcanic region, northeastern China. Sci. China Ser. D-Earth Sci. 54, 17461753, doi: 10.1007/s11430-011-4254-6. 
Zhang, H.P., Zhang, P.Z., Zheng, D.W., Zheng, W.J., Chen, Z.W., Wang, W.T., 2014. Transforming the

Miocene Altyn Tagh fault slip into shortening of the northwestern Qilian Shan: insights from the drainage basin geometry. Terra Nova 26, 216-221, doi: 10.1111/ter.12089.

Zhang, J., Ji, J., Zhong, D.L., Ding, L., He, S., 2004. Structural pattern of eastern Himalayan syntaxis in

Namjagbarwa and its formation process. Sci. China Ser. D-Earth Sci. 47, 138-150, doi:10.1360/02yd0042.

Zhang, P.Z., Molnar, P., Downs, W.R., 2001. Increased sedimentation rates and grain sizes 2-4 Myr ago due to the influence of climate change on erosion rates. Nature 410, 891-897, doi:10.1038/35073504.

Zhong, D.L., Ding, L., 1996. Discovery of high-pressure basic granulite in Namjagbarwa area, Tibet, China. Chin. Sci. Bull. 41, 87-88, doi:10.1360/sb1996-41-1-87.

Zhu, S., Wu, Z. H., Zhao, X.T., Li, J.P., Wang, H., 2012. Middle-Late Pleistocene Glacial Lakes in the Grand Canyon of the Tsangpo River, Tibet. Acta Geologica Sinica-English Edition 86, 266-283, doi: 10.1111/j. 1755-6724.2012.00627.x.

\section{List of Figures}

Fig. 1. Geomorphic map of the SE Tibetan Plateau. (A) Geographical overview of the eastern Himalayan syntaxis. The red line indicates the location of the Yarlung Tsangpo Gorge. DongJML Fault - Dong Jiu Mi Lin Fault, ANQ Fault - A'NiQiao Fault. The inset map is the drainage basin of the whole Yarlung Tsangpo River, in which the blue lines are rivers used to calculate the exponent of area, $m$. The elevation data are from SRTM DEM with a resolution of $90 \mathrm{~m}$ (http://srtm.csi.cgiar.org/SELECTION/inputCoord.asp). The topography data localized in the gorge (B) are rectified by Aster Global DEM (http://earthexplorer.usgs.gov/) for the poor data quality of the SRTM DEM. The locations of drillings are from Wang et al. (2014). (B) Geographical overview of the Eastern Himalaya syntax. The locations of the Yarlung Tsangpo knickpoint and the end of the gorge are from Wang et al. (2014). (C) Geologic map of the Yarlung Tsangpo Gorge. The geology was digitized from Chinese geologic maps at a scale of 1:500,000 (Tibet autonomous region geological and mineral exploration and Development Bureau, 1999). The gray arrows show flow direction.

Fig. 2. $\chi-z$ plots of the Yarlung Tsangpo River based on a series of $\theta$ values. (A)-(C) are the $\chi-z$ plots based on different $\theta$ values, $0.3,0.5,0.7$. The red line is trunk stream, and the black lines are tributaries. (D) Elevation scatter in $\chi-z$ plots as a function of $\theta$. The $\chi$ values are calculated with $A_{0}=1 \mathrm{~m}^{2}$. 
Fig. 3. The pattern of channel steepness along the trunk stream and its tributaries.

Fig. 4. Schematic figure of a knickpoint migrating from point $\mathrm{A}$ to $\mathrm{D}$ in a time step $d t$ (from time $t$ to $t+d t$ ). In the figure, $t$ is time, $z$ is river channel elevation, and $x$ is upstream distance from the drainage basin mouth. The blue solid line indicates a river profile in time $t$. The red dashed line indicates a river profile in time $t+d t$.

Fig. 5. Schematic of knickpoint migration upstream. (A)-(B) The stream profile experiences spatially uniform rock uplift rates. (C)-(D) The rock uplift rate is slightly larger in the downstream reach, but it cannot balance the difference in incision rates around the knickpoint. (E)-(F) The rock uplift rate downstream increases to balance the difference in incision rates, generating a stationary knickpoint. $(\mathrm{G})-(\mathrm{H})$ The rock uplift rate downstream increases and outpaces the difference of incision rates, forming a local deposition center (yellow area). The length of arrows represents the magnitude of rock uplift rates.

Fig. 6. Trunk stream profile of the Yarlung Zangpo River downstream of drilling no.1. (A) Elevation profile and Zircon (U-Th)/He annealing age (Zeitler et al., 2014). The profile is divided into four segments for distinct channel slope as shown in a different color. (B) $\chi-z$ plot and drainage area. (C) The log-transformed slope-area plot of the trunk river. (D) The elevation and local channel steepness $(m=0.5$, length step $=5 \mathrm{~km})$ along the trunk river.

Fig. 7. Relationship between mean exhumation rates and Zircon (U-Th)/He annealing ages. Based on a onedimension, steady-state thermal diffusion equation, we derived this relationship by the AGE2EDOT program (http://campuspress.yale.edu/markbrandon/software/386-2/).

Fig. 8. Bivariate linear regression between exhumation rates and channel steepness indices. The red line is the regression result. Gray dashed lines represent $95 \%$ confidence intervals.

Fig. 9. Channel profile of Yarlung Tsangpo River (revised from Wang et al., 2014). The shallow yellow zone is deposition. The thick gray line beneath the deposition zone is the modeled bedrock profile. The black dashed line indicates the reconstructed valley bottom before uplift of Tsangpo Gorge $2.5 \mathrm{Ma}$. 
Fig. 10. The pattern of channel steepness in the southern Tibetan Plateau. The geology is digitized from Chinese geologic maps at a scale of 1:500,000 (Tibet autonomous region geological and mineral exploration and Development Bureau, 1999). The gray arrows indicate the flow direction of the trunk river.

Fig. 11. Channel steepness indices of Yarlung Tsangpo River and its tributaries. Precipitation data are from National Data Sharing Infrastructure of Earth System Science (www.geodata.cn). The gray arrows indicate the flow direction of the trunk river.

Fig. 12. Log-transformed slope-area plot of the tributaries. (A) Stream nos. 3, 5, 6, and 8 are combined together. (B) Stream nos. 21-25 are combined together. (C) Stream nos. 26-30 are combined together. (D) Stream nos. 31-35 are combined together. The stream number is shown in Fig. 11.

Fig. 13. $\chi-z$ plots of tributaries of the upstream reaches. The black crosses represent knickpoints, and the river number corresponds to Fig. 10. 


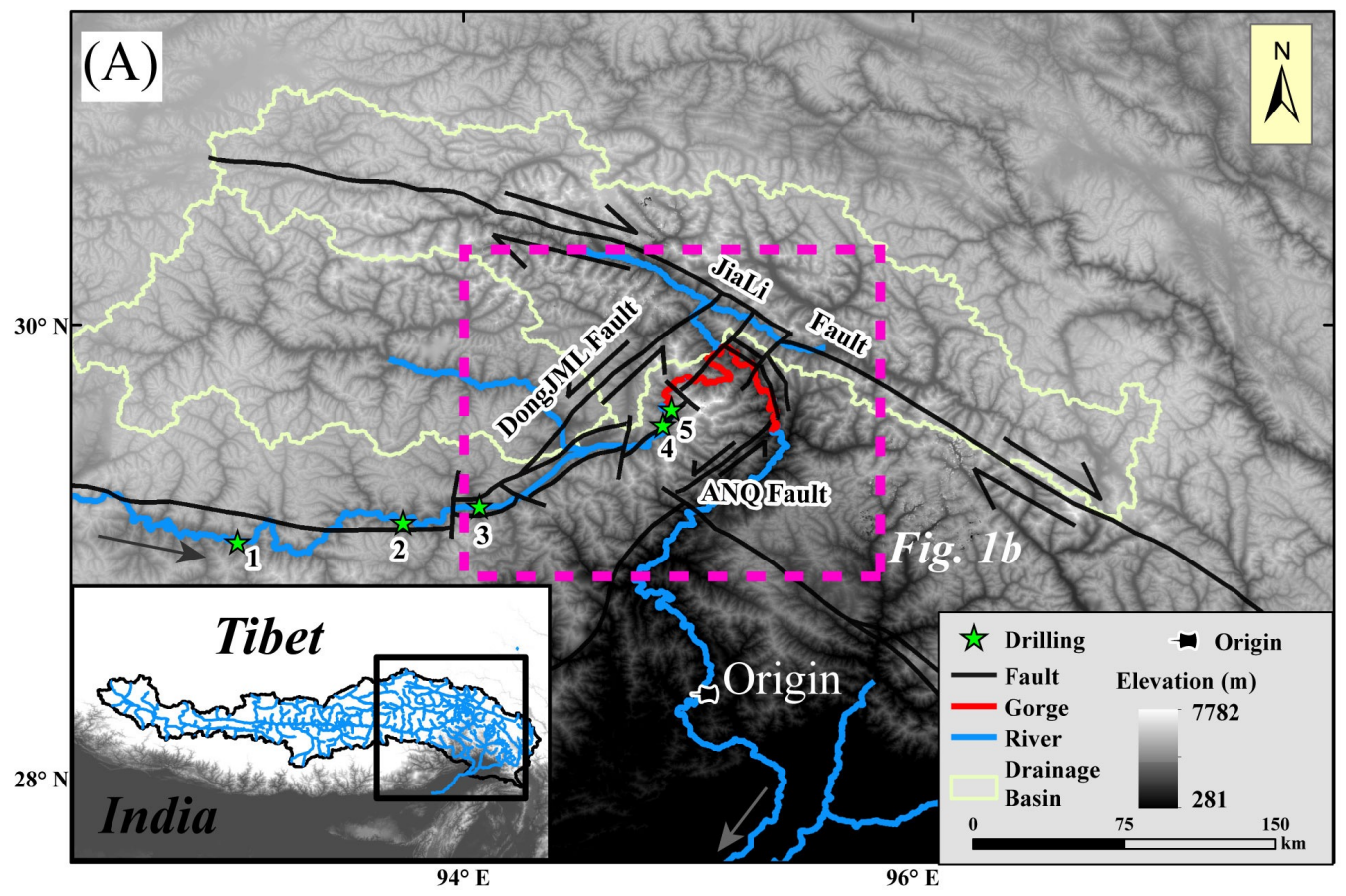

Figure 1A

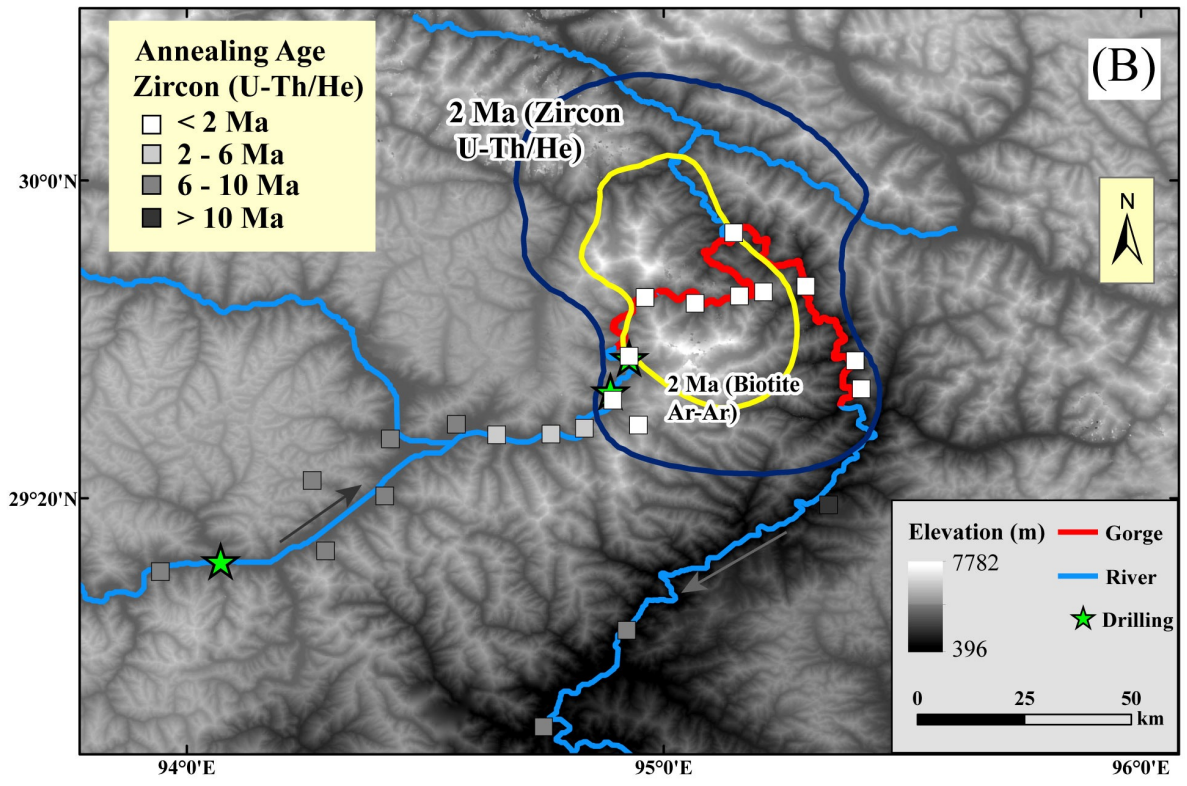

Figure 1B 


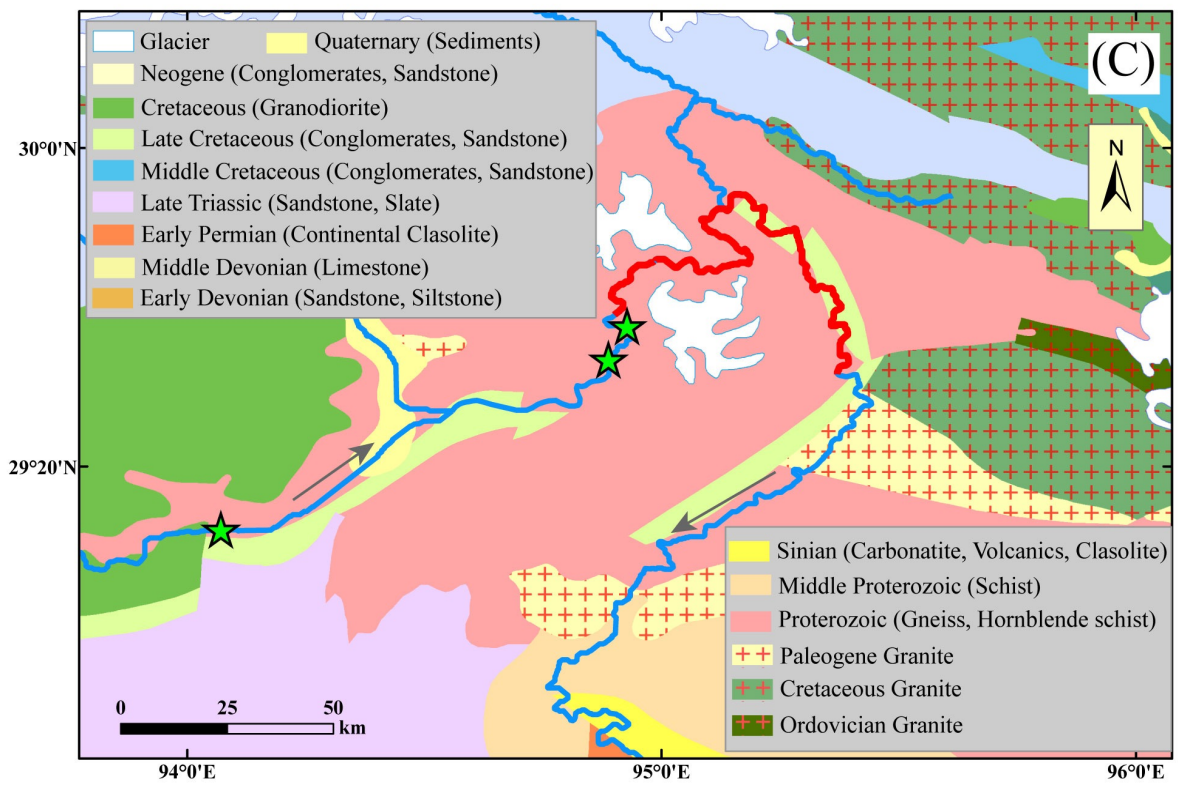

Figure 1C
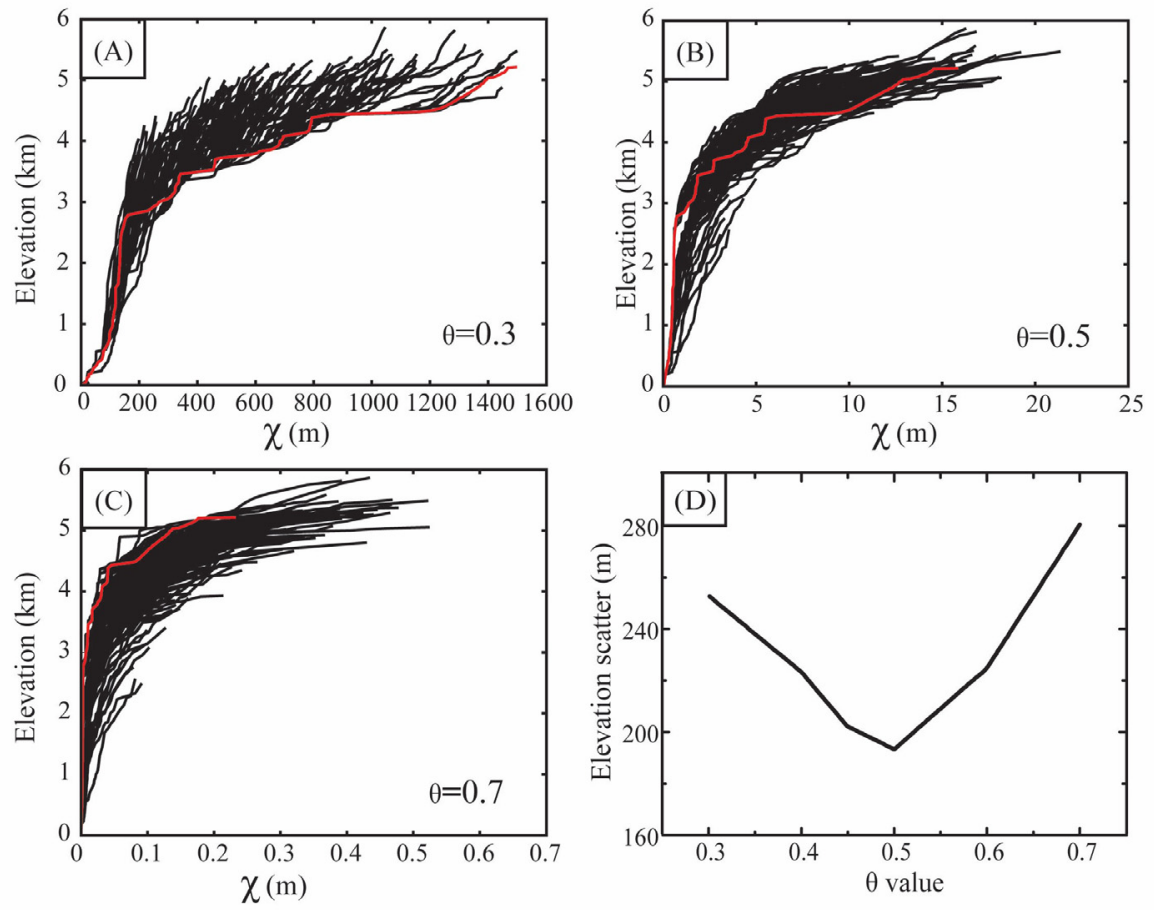

Figure 2A-D 


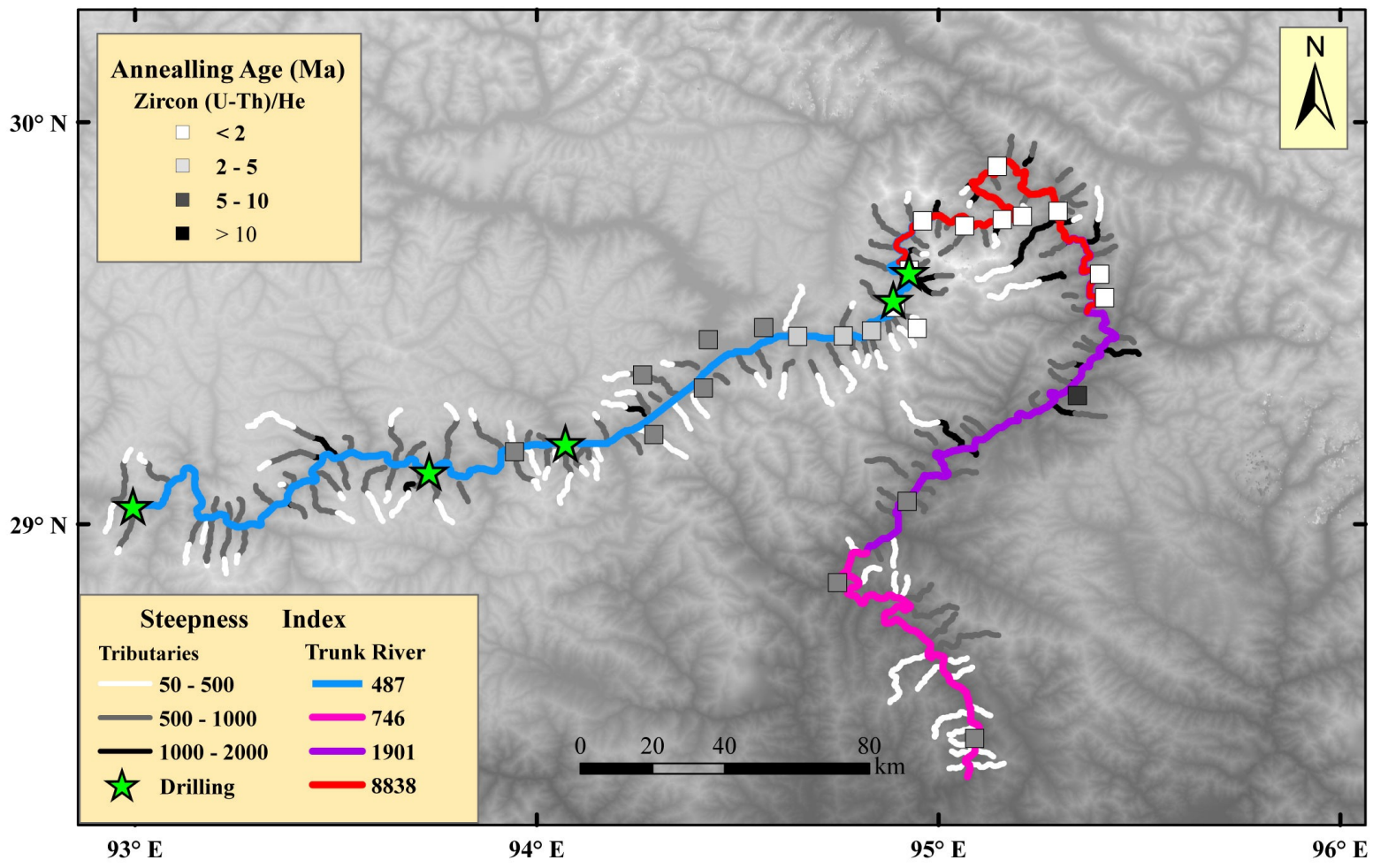

Figure 3

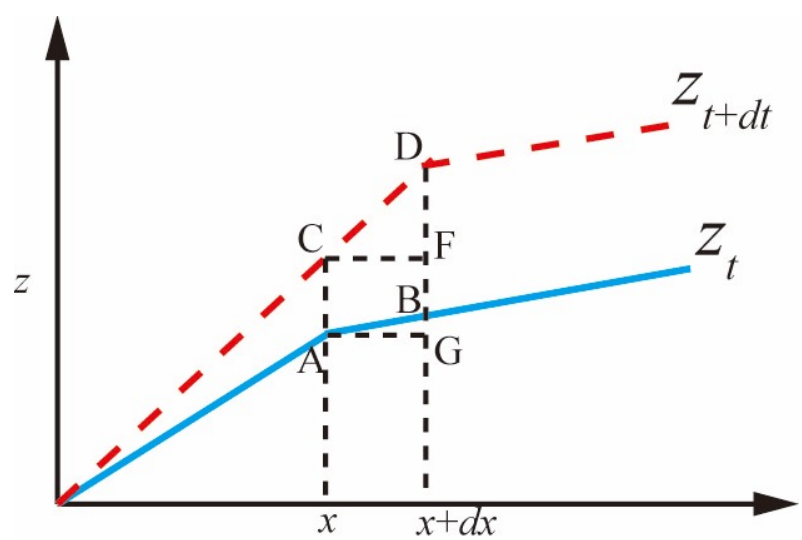

Figure 4 

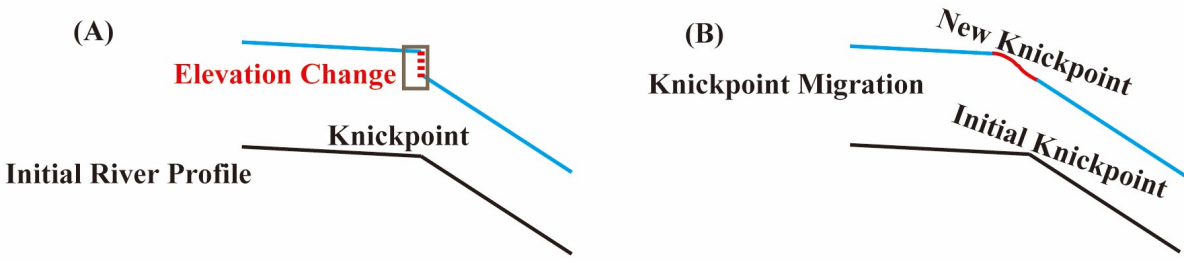

(C)

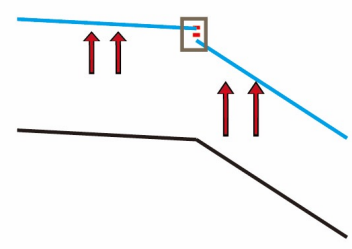

(D)

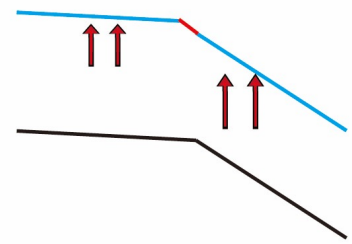

(E)

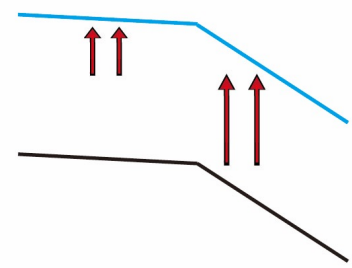

(F)

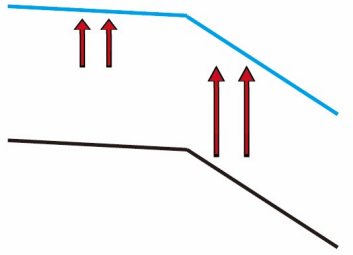

(G)

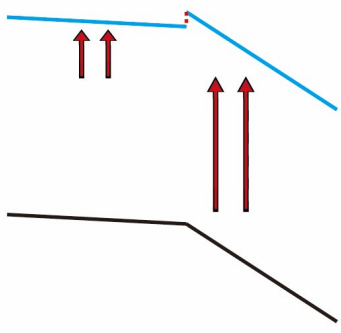

(H)

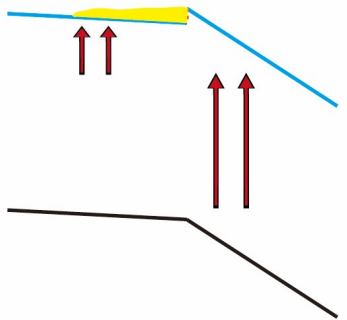

Figure 5A-H 

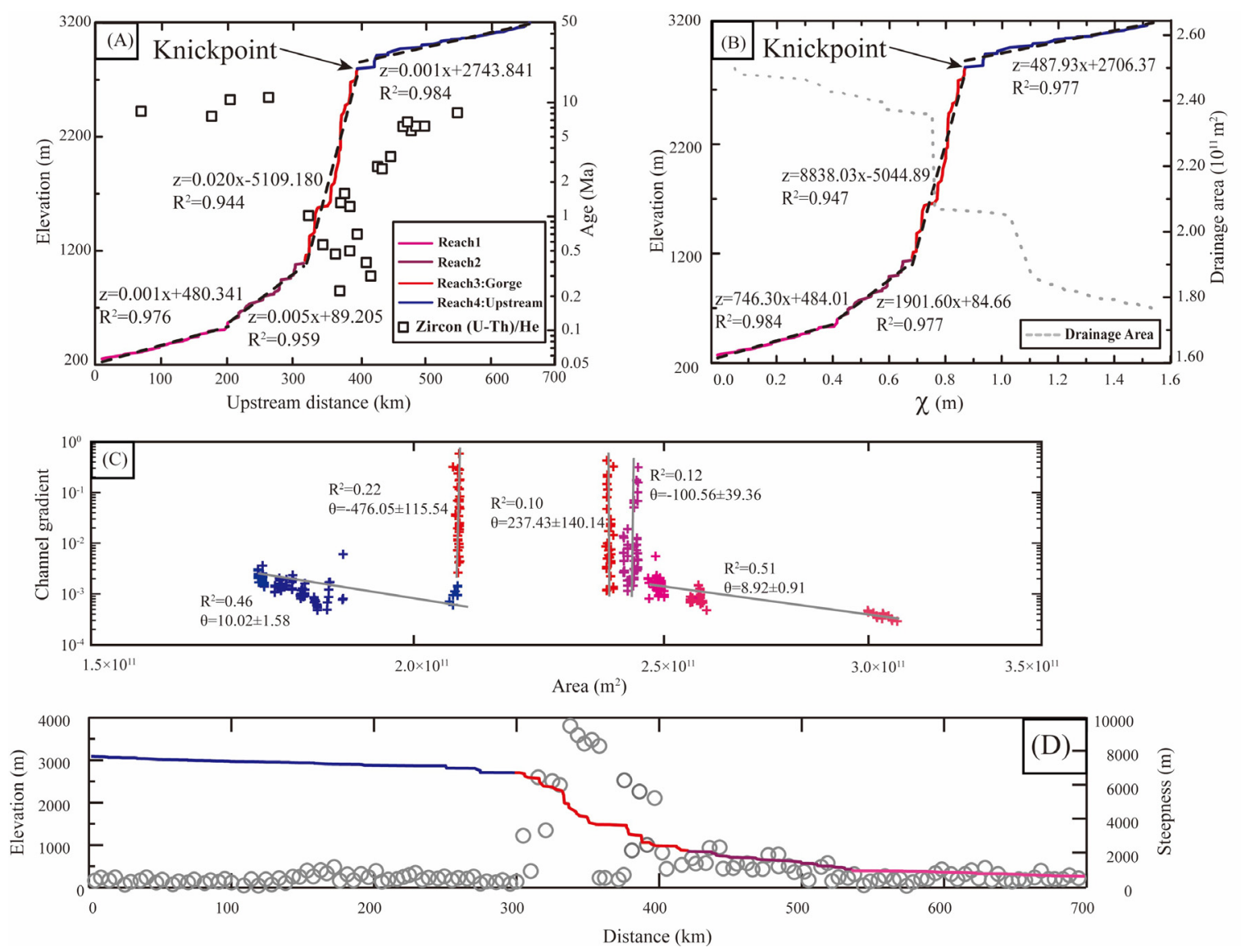

Figure 6A-D

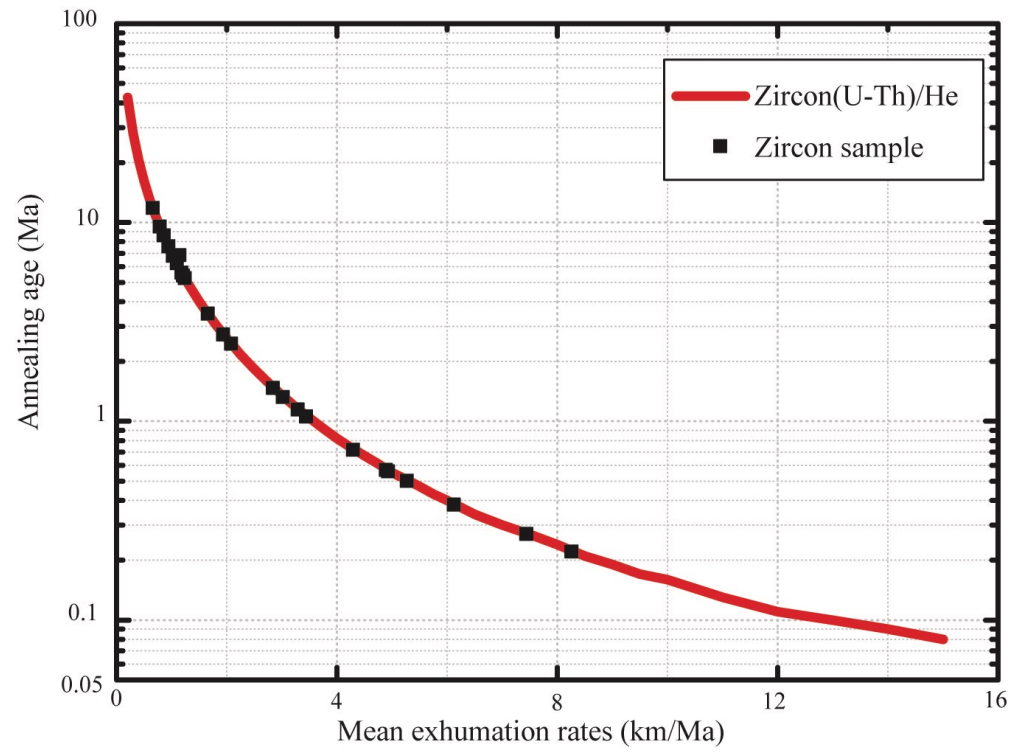

Figure 7 


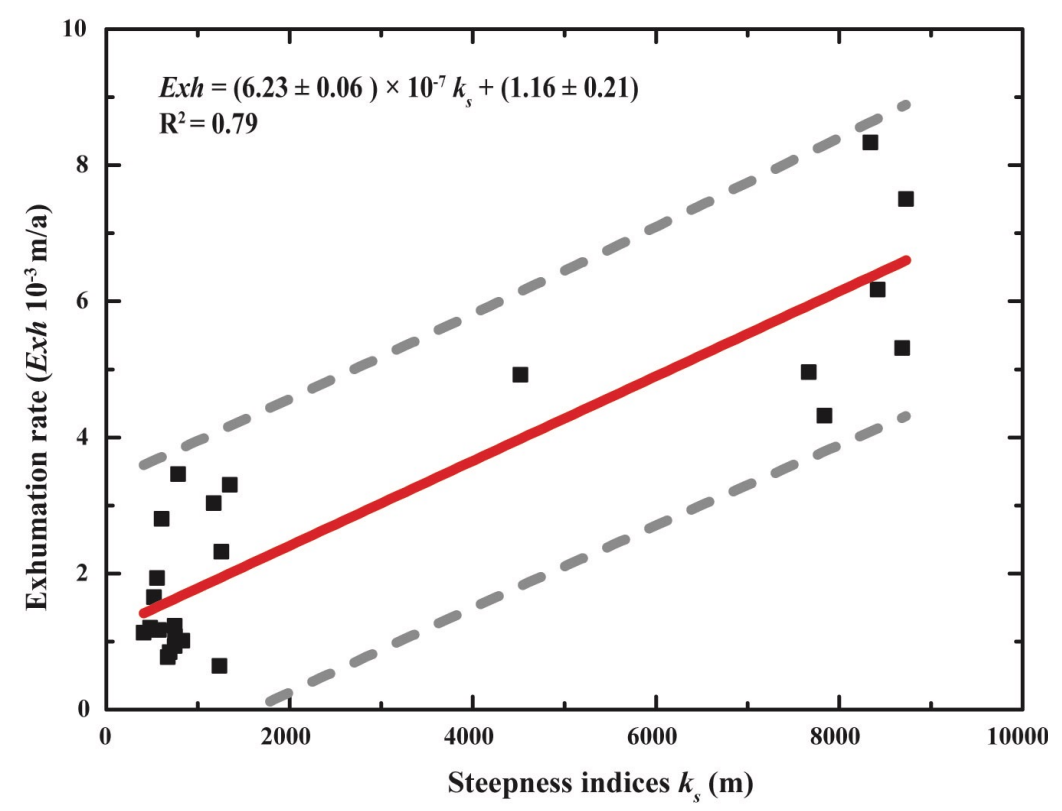

Figure 8

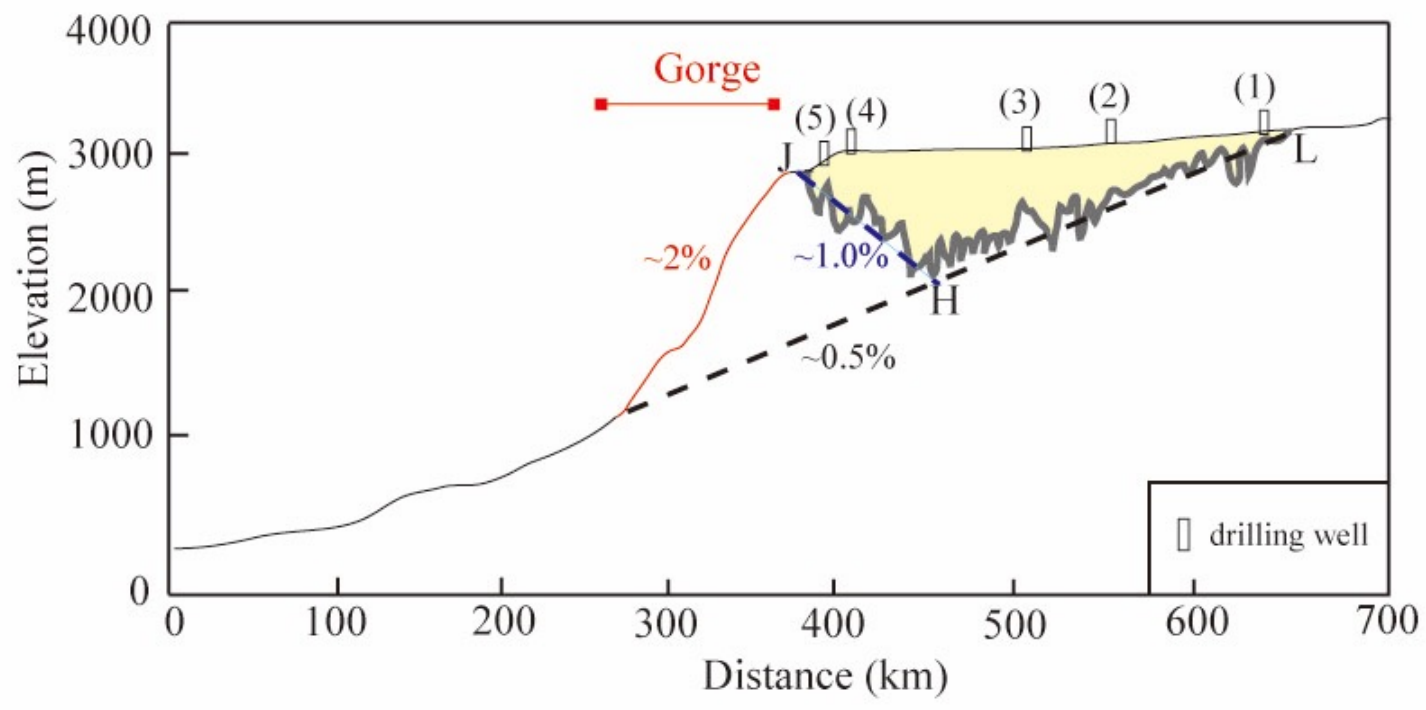

Figure 9 


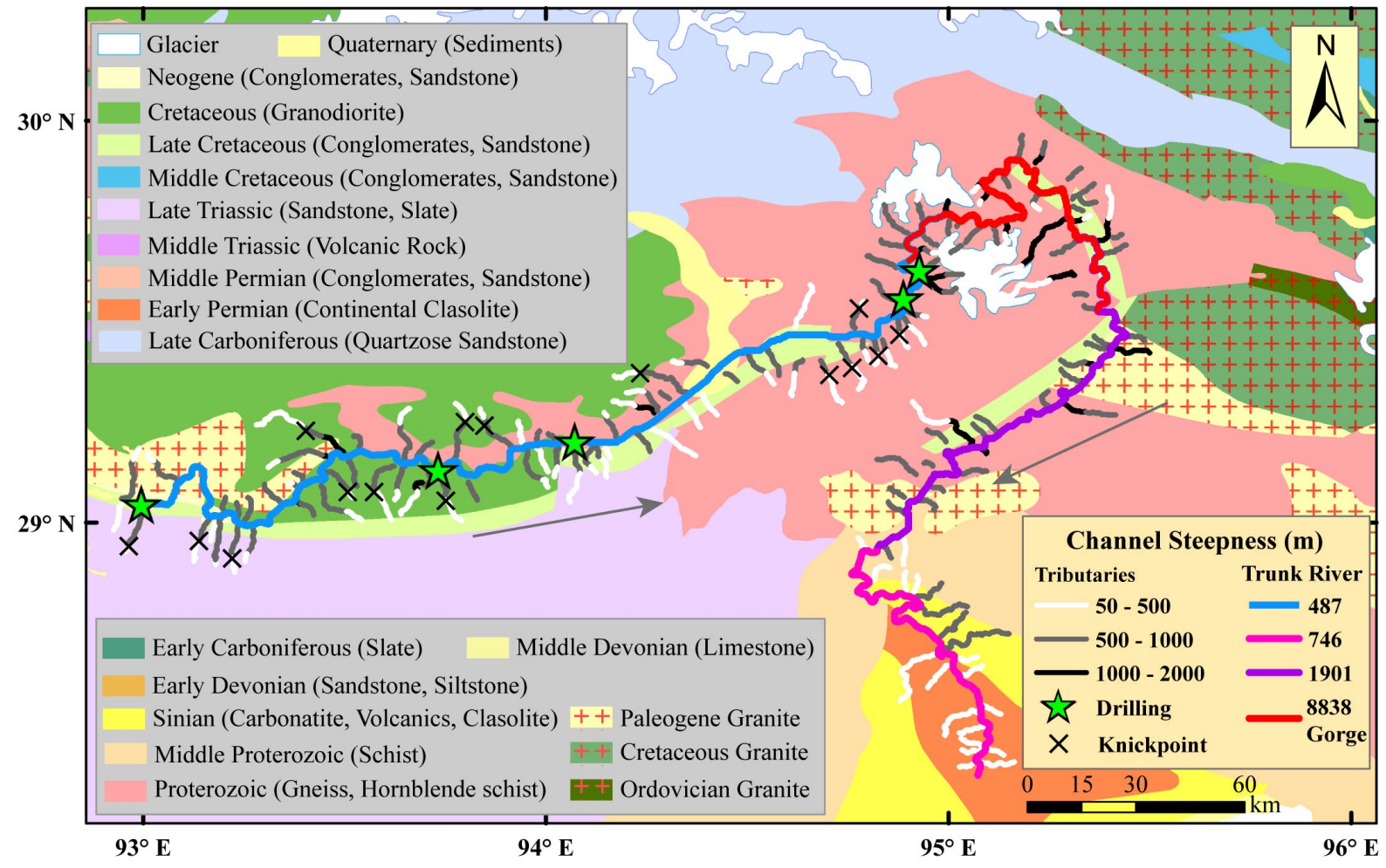

Figure 10 


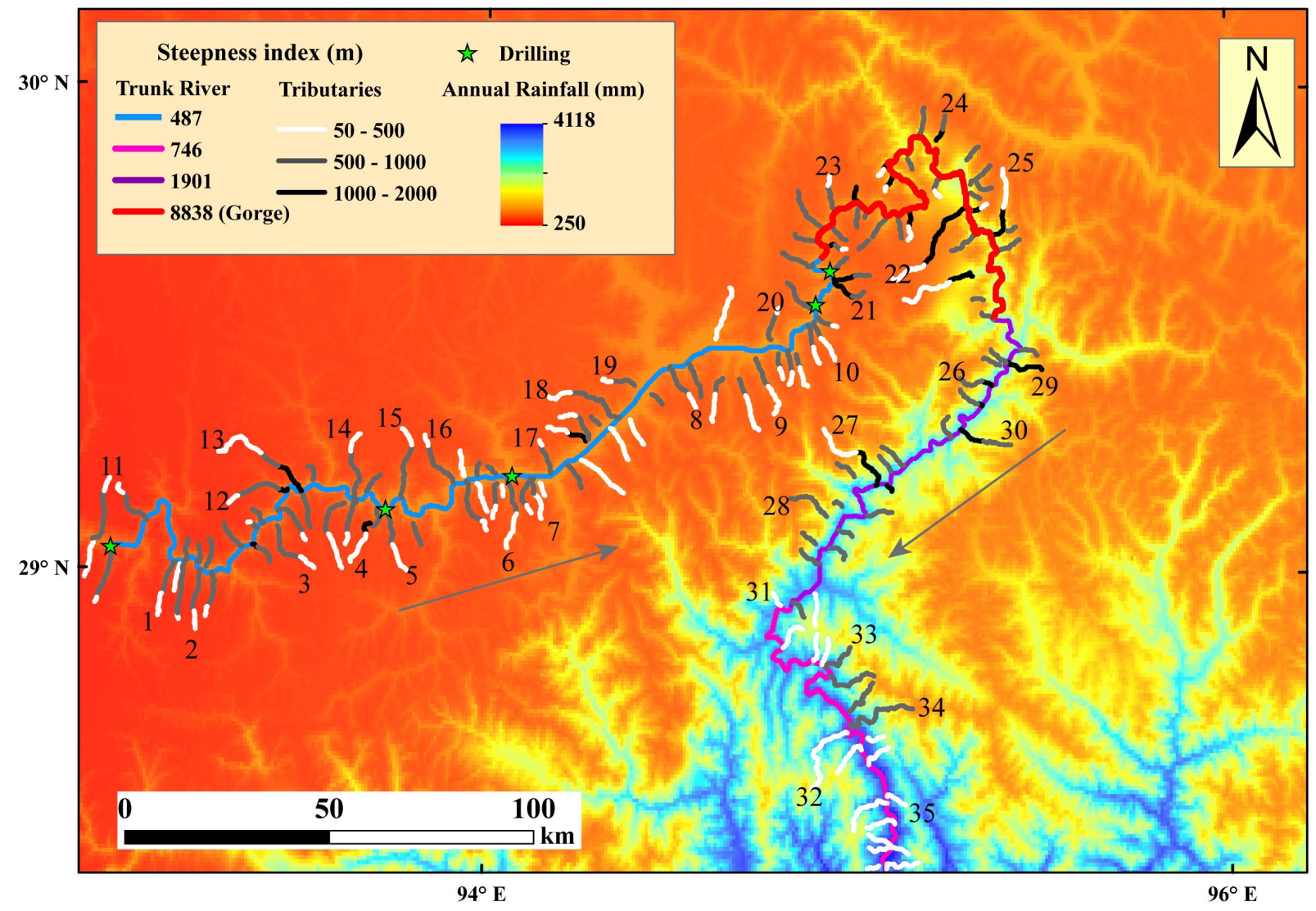

Figure 11 

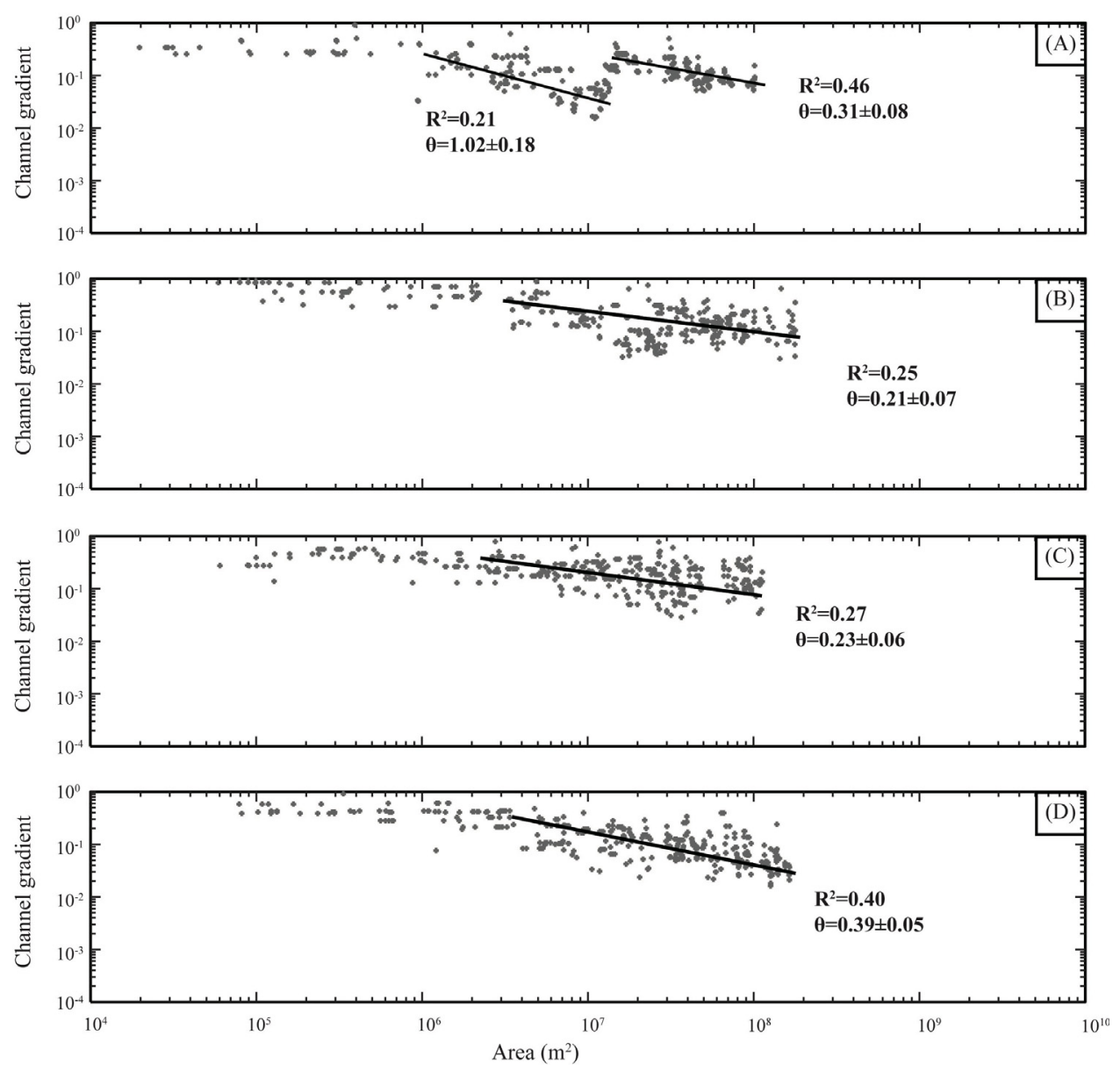

Figure 12

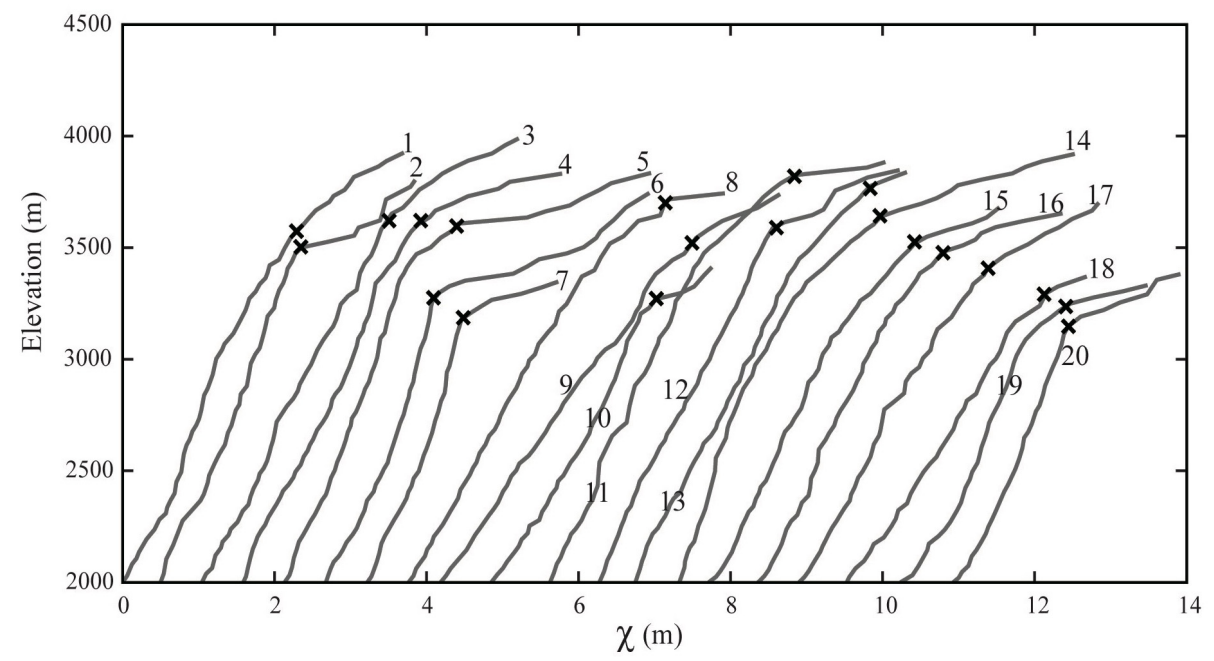

Figure 13 
Table 1 Parameters in the paper

\begin{tabular}{ll}
\hline Symbol & Meaning \\
\hline$K$ & Stream elevation and upstream distance \\
$A$ & Erodibility of river \\
$m, n$ & Drainage area \\
$k_{s}, \theta$ & Exponent of drainage area and channel gradient \\
, & Channel steepness and concavity \\
& Local channel gradient of reaches downstream and upstream of the knickpoint at time $t$ \\
, & Local channel gradient of reaches downstream of the knickpoint at time $t+d t$ \\
$v$ & Rock uplift rate of reaches downstream and upstream of the knickpoint at time $t$ \\
\hline
\end{tabular}

